\title{
African swine fever: Update on Eastern, Central and Southern Africa
}

\author{
Léopold K. Mulumba-Mfumu ${ }^{1,2}$ | Claude Saegerman ${ }^{2}$ (1) | Linda K. Dixon ${ }^{3}$ | Kapanga \\ C. Madimba $^{1}$ | Eric Kazadi ${ }^{1}$ | Ndeji T. Mukalakata ${ }^{1}$ | Chris A. L. Oura ${ }^{4}$ | Erika Chenais ${ }^{5}$ | \\ Charles Masembe $^{6}$ | Karl Ståhl ${ }^{5}$ | Etienne Thiry ${ }^{7}$ (D) | Mary Louise Penrith ${ }^{8}$ (D)
}

${ }^{1}$ Department of Clinical Sciences, Faculty of Veterinary Medicine, University of Kinshasa, Kinshasa, Democratic Republic of the Congo

${ }^{2}$ Research Unit of Epidemiology and Risk Analysis Applied to Veterinary Sciences (UREAR- ULiège), Fundamental and Applied Research for Animals \& Health (FARAH) Center, Faculty of Veterinary Medicine, University of Liege, Liege, Belgium

${ }^{3}$ Pirbright Institute, Woking, UK

${ }^{4}$ School of Veterinary Medicine, Faculty of Medical Sciences, University of the West Indies, Champ Fleurs, Trinidad and Tobago

${ }^{5}$ Department of Disease Control and Epidemiology, SVA, Uppsala, Sweden

${ }^{6}$ College of Natural Sciences, Makerere University, Kampala, Uganda

${ }^{7}$ Veterinary Virology and Animal Viral Diseases, Fundamental and Applied Research for Animals \& Health (FARAH) Center, Faculty of Veterinary Medicine, University of Liege, Liege, Belgium

${ }^{8}$ Department of Veterinary Tropical

Diseases, Faculty of Veterinary

Science, University of Pretoria,

Onderstepoort, South Africa

Correspondence

M. L. Penrith, Department of Veterinary

Tropical Diseases, Faculty of Veterinary

Science, University of Pretoria,

Onderstepoort, South Africa.

Email:marylouise@vodamail.co.za

\begin{abstract}
Control of African swine fever (ASF) in countries in Eastern, Central and Southern Africa (ECSA) is particularly complex owing to the presence of all three known epidemiological cycles of maintenance of the virus, namely an ancient sylvatic cycle involving the natural hosts and vectors of the disease as well as domestic cycles with and without involvement of natural vectors. While the situation is well documented in some of the countries, for others very little information is available. In spite of the unfavourable ASF situation, the pig population in the sub-region has grown exponentially in recent decades and is likely to continue to grow in response to rapid urban growth resulting in increasing demand for animal protein by populations that are no longer engaged in livestock production. Better management of ASF will be essential to permit the pig sector to reach its full potential as a supplier of high quality protein and a source of income to improve livelihoods and create wealth. No vaccine is currently available and it is likely that, in the near future, the sub-region will continue to rely on the implementation of preventive measures, based on the epidemiology of the disease, to avoid both the devastating losses that outbreaks can cause and the risk the sub-region poses to other parts of Africa and the world. The current situation in the ECSA sub-region is reviewed and gaps in knowledge are identified in order to support ongoing strategy development for managing ASF in endemic areas.
\end{abstract}

\section{KEYWORDS}

African swine fever, Central Africa, Eastern Africa, epidemiology, knowledge gaps, management, pig production, socio-economic impact, Southern Africa

\section{1 | INTRODUCTION}

African swine fever (ASF) is a haemorrhagic fever of pigs that can result in up to 100 per cent mortality. It is caused by a large DNA virus that is the only known member of the genus Asfivirus and family Asfarviridae (Dixon et al., 2005). Only members of the family Suidae are susceptible to the infection. Confirmation of ASF as a disease that differed from classical swine fever was first obtained in Kenya, where an association with warthogs (Phacochoerus africanus) was recognized (Montgomery, 1921).

The epidemiology is complex. Three cycles of transmission have been confirmed in sub-Saharan Africa: two cycles that involve soft ticks of the Ornithodoros moubata complex and a cycle involving circulation among domestic pigs. The virus is believed to have evolved 
in Eastern and Southern Africa in an ancient sylvatic cycle between common warthogs and argasid ticks of the Ornithodoros moubata complex that live in their burrows (warthog-tick cycle) (Plowright, Thomson, \& Neser, 1994). Recent studies suggest that the cycle originated in the early 1700s in Africa (Alkhamis et al., 2018; Michaud, Randriamparany, \& Albina, 2013). Early attempts to infect domestic pigs by contact with warthogs failed (De Kock, Robinson, \& Keppel, 1940; Montgomery, 1921; Thomson, Gainaru, \& Van Dellen, 1980). This is attributed to the fact that adult warthogs do not develop sufficiently high viraemia (Jori et al., 2013; Thomson, 1985; Thomson et al., 1983). The ability of ticks of the genus Ornithodoros to transmit African swine fever virus (ASFV) to pigs was first demonstrated in Spain after the introduction of the virus in 1960 (Sánchez Botija, 1963). The involvement of ticks from warthog burrows in this cycle was first confirmed in Kenya, Uganda and Tanzania (Plowright, Parker, \& Peirce, 1969a, 1969b). Ornithodoros moubata complex ticks are competent biological vectors of ASFV, transmitting the virus transovarially, trans-stadially and sexually and to pigs when feeding on their blood via the saliva and the coxal fluid that is excreted while feeding (Plowright, Perry, \& Greig, 1974; Rennie, Wilkinson, $\&$ Mellor, 2001). Transmission of the virus from warthogs to ticks is explained by circulation of the virus maintained between neonatal warthogs that spend the first 4-6 weeks of life in the burrow, where the ticks inhabiting the burrow feed on them. Although no clinical signs of disease have been observed in young warthogs, they were reported to develop sufficiently high viraemia to be able to infect ticks (Thomson, 1985; Thomson et al., 1983).

Warthogs are resistant to the pathogenic effects of the virus, so the warthog-tick cycle is not characterized by overt disease or mortality. On the contrary, the disease has devastating socio-economic consequences in domestic pigs due to its high lethality. A domestic pig-tick cycle between domestic pigs and Ornithodoros ticks that live in their shelters (pig-tick cycle) has been demonstrated in Malawi and Mozambique and may be more widespread (Haresnape, Lungu, \& Mamu, 1985, 1987; Quembo, Jori, Heath, Pérez-Sánchez, \& Vosloo, 2016; Simulundu et al., 2017; Wilkinson, Pegram, Berry, Lemche, \& Schels, 1988). A domestic cycle dependent on direct or indirect transmission amongst domestic pig populations without involvement of wild hosts or vectors occurs throughout the region.

Countries in Eastern and Southern Africa are home to all three cycles and the area remains important in the maintenance and spread of the disease. The introductions of ASFV into countries outside the African region as well as West Africa, where the warthog-tick cycle is not present, have been traced through molecular phylogenetic studies to viruses that were circulating in the Eastern, Central and Southern Africa (ECSA) region. The presence of the disease in Africa is seen as a significant continuous threat to countries with industrialized pig farming that derive high revenues from pork exports (FAO, 2012c; Sánchez-Vizcaíno, Mur, \& Martínez-López, 2013; Vergne et al., 2017).

By the 1960s ASF outbreaks had been reported from the majority of Eastern and Southern African countries (Table 1). However, until ASF was introduced into Europe for the first time, relatively little importance was attached to the disease. Domestic pigs belonging to
European settlers were protected by ensuring separation from warthogs and it is likely that ASF events in traditionally kept free-range pigs largely escaped the notice of the veterinary services. The devastating effects of the disease in non-African countries with large and well developed pig industries highlighted the very real threat that it posed to pig production as well as the ease with which it became endemic and the challenges for eradication (Costard, Wieland, et al., 2009; Wilkinson, 1984). During the ensuing decades, both pig production and ASF became increasingly important and widespread in Africa as well.

Although many countries in West Africa are at present endemically infected, the history of ASF in that region is more recent and likely due to introductions that occurred mainly in the late 1950 s and again in the 1990s, with no evidence of a pre-existing sylvatic cycle (Brown, Penrith, Fasina, \& Beltrán-Alcrudo, 2018). Also in the 1990s, an increase in ASF outbreaks, sometimes after long periods of absence, was noted in Eastern and Southern Africa, including in countries and areas previously unaffected by ASF (Penrith, Vosloo, Jori, \& Bastos, 2013). The majority of the outbreaks for which the origin could be established were not related to the sylvatic cycle, but instead linked to movement of infected pigs or products. However, for a large number of outbreaks the origin remains unknown. The complex epidemiology of ASF in the ECSA region, where 24 p72 genotypes have been reported to date (Quembo, Jori, Vosloo, \& Heath, 2018), makes it important to have a more complete picture of the situation to support control and prevention strategies.

The purpose of this review is to summarize the information currently available on ASF in the historically endemic areas of ECSA, in order to highlight the socio-economic importance of the disease and identify knowledge gaps that could influence the ability to manage the disease. For the purposes of the study, the composition and terminology of the United Nations Geoscheme for Africa (https://en.wikipedia.org/wiki/United_Nations_geoscheme_for_Africa) have been used to allocate countries to sub-regions (Figure 1). Under this classification, according to FAOSTAT, populations of domestic pigs are present in 15 countries in Eastern Africa (Burundi, Ethiopia, Kenya, Madagascar, Malawi, Mauritius, Mozambique, Réunion, Rwanda, Seychelles, Somalia, Tanzania, Uganda, Zambia and Zimbabwe), all nine countries in Central Africa (Angola, Cameroon, Central African Republic, Chad, Republic of the Congo, Democratic Republic of the Congo (DRC), Equatorial Guinea, Gabon and São Tomé e Principe) and all five countries in Southern Africa (Botswana, Eswatini [formerly Swaziland], Lesotho, Namibia and South Africa). Among these 29 countries, only seven (Equatorial Guinea, Eswatini, Gabon, Lesotho, Réunion, Seychelles and Somalia) have never reported ASF.

\section{2 | PIG PRODUCTION AND THE SOCIO-ECONOMIC IMPACT OF ASF IN ECSA COUNTRIES}

Pig production is similar throughout sub-Saharan Africa, comprising of traditional free-range systems, smallholder production particularly 
TAB LE 1 Summary of knowledge of ASF in East, Central and Southern African countries

\begin{tabular}{|c|c|c|c|}
\hline Country & $\begin{array}{l}\text { Infection in } \\
\text { warthogs/Ornithodoros moubata } \\
\text { complex ticks }\end{array}$ & $\begin{array}{l}\text { Infection in pig-associated } \\
\text { Ornithodoros moubata } \\
\text { complex ticks }\end{array}$ & ASF outbreaks reported in domestic pigs \\
\hline \multicolumn{4}{|l|}{ East Africa } \\
\hline Burundi & Not investigated & Not investigated & $\begin{array}{l}\text { Reporting irregular since } 1979 \text { but reflects that } \\
\text { outbreaks occur frequently }\end{array}$ \\
\hline Ethiopia & Not investigated & Not investigated & Since 2011 (Achenbach et al., 2017) \\
\hline Kenya & $\begin{array}{l}\text { Present (DeTray, 1963; Plowright } \\
\text { et al., 1994) }\end{array}$ & Not described & $\begin{array}{l}\text { First outbreaks reported in } 1909 \text { (Montgomery, } \\
\text { 1921); endemic in domestic pigs in western Kenya } \\
\text { (Lichoti et al., 2016) }\end{array}$ \\
\hline Madagascar & Warthogs not present & $\begin{array}{l}\text { Reported (Ravaomanana et } \\
\text { al., 2010) }\end{array}$ & Since 1998; regular outbreaks \\
\hline Malawi & $\begin{array}{l}\text { Positive serology in warthogs } \\
\text { (Haresnape, Lungu, \& Mamu, } \\
\text { 1985) }\end{array}$ & $\begin{array}{l}\text { High infection rates in } \\
\text { endemic area (Haresnape et } \\
\text { al., 1988) }\end{array}$ & $\begin{array}{l}\text { Since } 1932 \text { (Turnbull, 1932, 1933, 1934; ); regular } \\
\text { outbreaks }\end{array}$ \\
\hline Mauritius & $\begin{array}{l}\text { Warthogs not present (no African } \\
\text { wild pigs) }\end{array}$ & $\begin{array}{l}\text { Ornithodoros moubata not } \\
\text { present (Jori et al., 2013) }\end{array}$ & $\begin{array}{l}\text { Introduced in 2007, eradicated by } 2008 \text { (Lubisi et al., } \\
\text { 2009) }\end{array}$ \\
\hline Mozambique & $\begin{array}{l}\text { Positive serology, virology } \\
\text { (Quembo et al., 2016, 2018) }\end{array}$ & $\begin{array}{l}\text { Low incidence of infected } \\
\text { ticks in pig sties (Quembo } \\
\text { et al., 2018) }\end{array}$ & $\begin{array}{l}\text { Since } 1954 \text { (confirmed de Abreu, Valadão, Limpo } \\
\text { Serra, Ornelas Mário, \& Sousa Montenegro, 1962) }\end{array}$ \\
\hline Rwanda & Not investigated & Not investigated & $\begin{array}{l}\text { No reports found before } 2002 \text {; reporting irregular } \\
\text { but reflects that outbreaks occur frequently }\end{array}$ \\
\hline Tanzania & $\begin{array}{l}\text { Confirmed in warthogs and ticks } \\
\text { (Plowright, Parker, \& Peirce, } \\
\text { 1969a; Plowright et al., 1994) }\end{array}$ & Not reported & $\begin{array}{l}\text { First reported in } 1914 \text { (DeTray, 1963; Montgomery, } \\
\text { 1921; Wambura et al., 2006); sporadic outbreaks } \\
\text { reported throughout the country }\end{array}$ \\
\hline Uganda & $\begin{array}{l}\text { Confirmed in warthogs and ticks } \\
\text { (Plowright et al., 1994) }\end{array}$ & Not reported & Reported regularly; endemic in domestic pigs \\
\hline Zambia & $\begin{array}{l}\text { Confirmed in ticks in warthog } \\
\text { burrows (Wilkinson et al., 1988) }\end{array}$ & Not reported & $\begin{array}{l}\text { Reported from the Eastern Province since 1912; } \\
\text { endemic in pigs in Eastern Province (Wilkinson et } \\
\text { al., 1988), sporadic elsewhere }\end{array}$ \\
\hline Zimbabwe & $\begin{array}{l}\text { Confirmed in warthogs and ticks } \\
\text { (Plowright et al., 1994) }\end{array}$ & Not investigated & Occasional outbreaks $(1977,1992,2015)$ \\
\hline \multicolumn{4}{|l|}{ Southern Africa } \\
\hline Botswana & $\begin{array}{l}\text { Positive serology in warthogs } \\
\text { (Simpson \& Drager, 1979) }\end{array}$ & Not investigated & Occasional outbreaks $(1953,1987,1999)$ \\
\hline Namibia & $\begin{array}{l}\text { Confirmed in warthogs and ticks } \\
\text { (Plowright et al., 1994; Thomson } \\
\text { et al., 1983) }\end{array}$ & Not investigated & $\begin{array}{l}\text { Sporadic outbreaks at least since the } 1920 \text { s } \\
\text { (Plowright et al., 1994); usually warthog associated }\end{array}$ \\
\hline South Africa & $\begin{array}{l}\text { Confirmed in ticks and warthogs } \\
\text { in a specified area (Thomson, } \\
\text { 1985; Thomson et al., 1983) }\end{array}$ & Not reported & $\begin{array}{l}\text { First reported in } 1928 \text { (Steyn, 1928); sporadic } \\
\text { outbreaks, in or as spillover from infected area, } \\
\text { warthog associated }\end{array}$ \\
\hline \multicolumn{4}{|l|}{ Central Africa } \\
\hline Angola & Not investigated & Not investigated & $\begin{array}{l}\text { Since } 1932 \text { (Gago da Camara, 1933); regular } \\
\text { outbreaks }\end{array}$ \\
\hline Cameroon & Investigated; no evidence found & $\begin{array}{l}\text { Investigated; no evidence } \\
\text { found }\end{array}$ & Since 1982 (Nana-Nukechap \& Gibbs, 1985) \\
\hline $\begin{array}{l}\text { Central African } \\
\text { Republic }\end{array}$ & Not investigated & Not investigated & Since 2010 (OIE) \\
\hline Chad & No evidence found & Not investigated & $\begin{array}{l}\text { Since } 2010 \text { (Bidjeh et al., 2015); unconfirmed earlier } \\
\text { reports }\end{array}$ \\
\hline $\begin{array}{l}\text { Congo, Republic } \\
\text { of }\end{array}$ & $\begin{array}{l}\text { A single record of infection in a } \\
\text { warthog (1978) (Plowright et al., } \\
\text { 1994) }\end{array}$ & Not investigated & $\begin{array}{l}\text { Outbreaks reported irregularly since 1975, believed } \\
\text { to be endemic (Gallardo, Ademun, et al., 2011a; } \\
\text { Gallardo, Anchuelo, et al., 2011b) }\end{array}$ \\
\hline
\end{tabular}


TABLE 1 (Continued)

\begin{tabular}{|c|c|c|c|}
\hline Country & $\begin{array}{l}\text { Infection in } \\
\text { warthogs/Ornithodoros moubata } \\
\text { complex ticks }\end{array}$ & $\begin{array}{l}\text { Infection in pig-associated } \\
\text { Ornithodoros moubata } \\
\text { complex ticks }\end{array}$ & ASF outbreaks reported in domestic pigs \\
\hline $\begin{array}{l}\text { Democratic } \\
\text { Republic of } \\
\text { Congo }\end{array}$ & Not investigated & Not investigated & $\begin{array}{l}\text { Since } 1939 \text { (Saliki et al., 1985); endemic in domestic } \\
\text { pigs with regular outbreaks }\end{array}$ \\
\hline $\begin{array}{l}\text { São Tomé e } \\
\text { Principe }\end{array}$ & No wild suids & Not investigated & $\begin{array}{l}\text { Single confirmed outbreak in } 1979 \text {, eradicated by } \\
1982\end{array}$ \\
\hline
\end{tabular}

${ }^{a}$ ASF has never been reported in the following countries in the region where pigs are kept: Equatorial Guinea, Eswatini, Gabon, Lesotho, Réunion (France) and Seychelles.

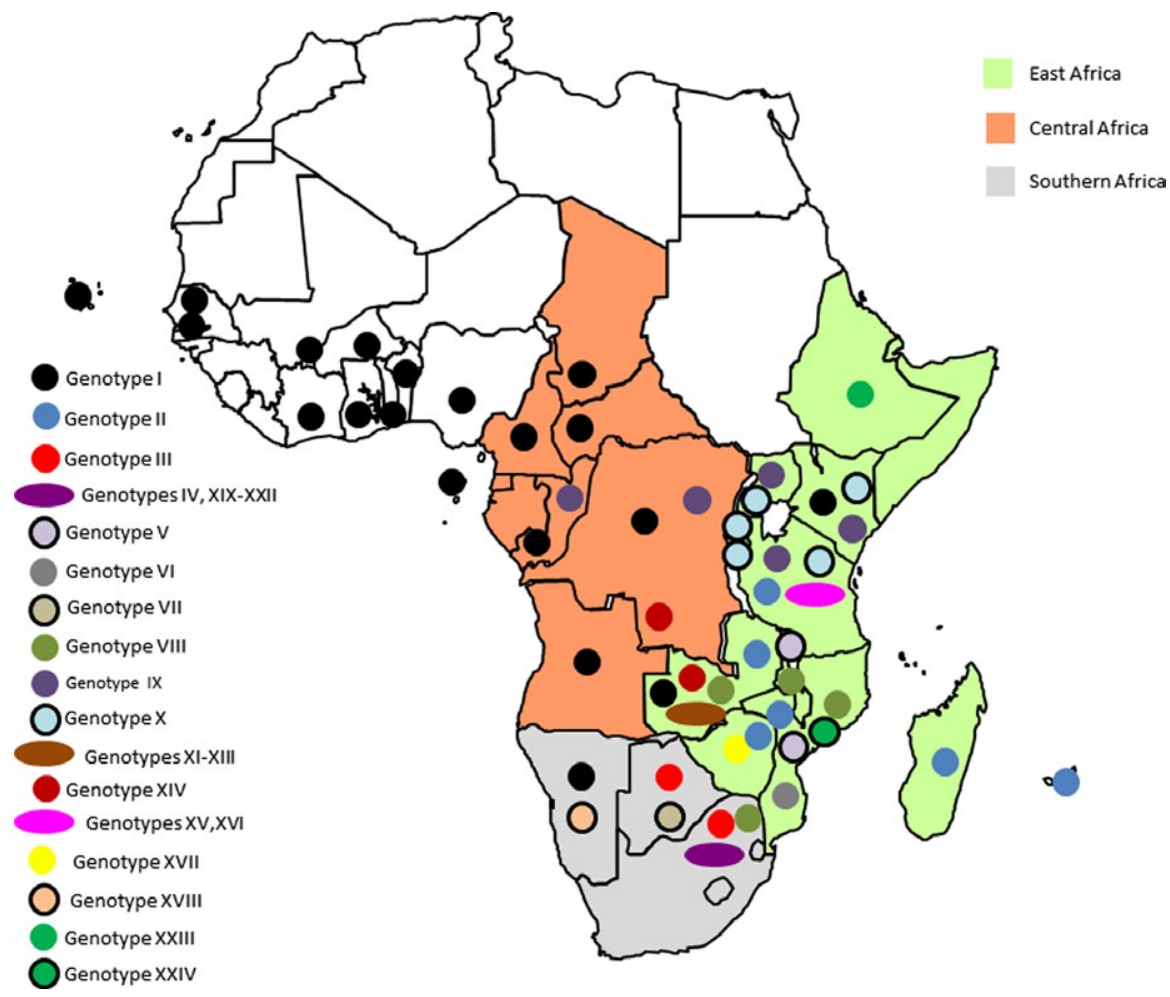

FIGURE 1 Distribution of the p72 genotypes in sub-Saharan Africa $81 \times 60 \mathrm{~mm}(300 \times 300 \mathrm{DPI})$

in the peri-urban context and small- to medium-scale mainly semi-intensive commercial production, with large-scale modern intensive pig farms being the exception (FAO, 2012a; 2012b; Penrith et al., 2013). While pigs at all levels are kept mainly for income generation, in traditional systems they may also have many other functions that include home consumption, cultural practices, environmental cleaning, mobile banks for cash expenses, provision of fat used for cooking and making soap and manure for fertilizer (Ampaire \& Rothschild, 2010; FAO, 2012a; 2012b; Halimani, Muchadeyi, Chimonyo, \& Dzama, 2012; Kamaghe, Meyer, Mlozi, \& Johansen, 2014; Mashatise, Hamudikuwanda, Dzama, Chimonyo, \& Kanengoni, 2005; Mutua, Dewey, \& Schelling, 2010; Nantima, Ocaido, Davies, et al., 2015; Ouma, Dione, Lule, Roesel, \& Pezo, 2014; Wilson \& Swai, 2014). In DRC, pigs have been used successfully to restore confidence and provide a source of income for women traumatized by war (Glass, Perrin, Kohli, \& Remy, 2014).

According to available statistics, pig production in Africa increased exponentially from about the 1980s (FAO, 2012c; Penrith et al., 2013). The increasing pig numbers are possibly partly due to improved census, but also to an increasing demand for affordable protein in rapidly expanding African cities by a growing middle class. Unfortunately, the growth in pig production was accompanied not only by an increase in reports of outbreaks in endemically infected ECSA countries but also by the introduction of ASF into many historically ASF-free countries in West and Central Africa (Penrith et al., 2013).

The opportunities for improving livelihoods through pig production are widely recognized, and ASF is now regarded as one of the major obstacles to pig production reaching its full potential. Apart from direct losses resulting from the disease, it acts as a major disincentive for significant investment in the pig sector by governments, funding agencies and farmers in spite of recognition of the potential contribution of pigs to food security and poverty alleviation (Chenais et al., 2015; Penrith et al., 2013). The occurrence of ASF is inextricably linked to pig production and trade. Domestic pigs are far more efficient at transmitting ASFV than African wild suids, so 
TABLE 2 Losses recorded in documented outbreaks of ASF 1980 - 2017 in ECSA

\begin{tabular}{|c|c|c|c|c|}
\hline Location & Year & Pigs lost & Financial loss & Source \\
\hline $\begin{array}{l}\text { Cameroon, W } \\
\text { Province }\end{array}$ & 1982 & 54,432 & $\$ 2.5$ million & $\begin{array}{l}\text { Nana-Nukechap \& } \\
\text { Gibbs, } 1985\end{array}$ \\
\hline Chad, Bassin Logone & 2010 & 139,810 & Not specified & Ban-Bo et al., 2012 \\
\hline DRC, Boende & 2007 & 4,500 & $\$ 1$ million & $\begin{array}{l}\text { DRC CVL, unpublished } \\
\text { report }\end{array}$ \\
\hline DRC, Kinshasa & 2010 & $>3,500$ & Not specified & $\begin{array}{l}\text { DRC CVL, unpublished } \\
\text { report }\end{array}$ \\
\hline Kenya, Nairobi area & 1997 & $5-6,000$ & Not specified & $\begin{array}{l}\text { FAO, unpublished } \\
\text { reports }\end{array}$ \\
\hline Madagascar & 1997-1999 & $\begin{array}{l}>50 \% \text { of } \\
\text { ca } 1.5 \\
\text { million }\end{array}$ & $€ 21$ million p.a. & $\begin{array}{l}\text { Thierry \& Capo-Chichi, } \\
2008\end{array}$ \\
\hline Mauritius & 2007 & $\begin{array}{l}\text { Ca. } \\
15,300\end{array}$ & $\$ 1$ million & Lubisi et al., 2009 \\
\hline Mozambique, South & 1993 & 20,000 & Not specified & $\begin{array}{l}\text { FAO, unpublished } \\
\text { reports }\end{array}$ \\
\hline Tanzania, Rombo & 2013 & 4,462 & $\$ 133,860$ & Swai \& Lyimo, 2014 \\
\hline $\begin{array}{l}\text { Uganda, Lira (one } \\
\text { farm) }\end{array}$ & 2014 & $\begin{array}{l}>138 \\
\text { (herd) }\end{array}$ & $\$ 20,000$ & $\begin{array}{l}\text { Chenais, Sternberg- } \\
\text { Lewerin, et al., } 2017\end{array}$ \\
\hline $\begin{array}{l}\text { Zambia, Kabwe (one } \\
\text { farm) }\end{array}$ & 1989 & 2,000 & $\$ 39,965$ & Samui et al., 1996 \\
\hline Zambia, Lusaka & 2013 & 6,500 & Not specified & Yabe et al., 2015 \\
\hline
\end{tabular}

in order to develop strategies for controlling disease transmission, it is important to understand how and where domestic pigs are exploited.

Reporting of ASF outbreaks in Africa is too incomplete to provide an accurate picture of the real losses caused by the disease. Outbreaks in endemic countries are often reported as unquantified presence, with more accurate data sometimes being available from research projects (Chenais et al., 2015). Perusal of the World Organisation for Animal Health (OIE) World Animal Health Information System (WAHIS) database that provides information on outbreaks from 2005 and the African Union Interafrican Bureaus for Animal Resources (AU-IBAR) Panafrican Animal Health Yearbooks (since 2013, renamed the Panafrican Animal Resources Yearbook) for the same period reveals discrepancies in the quantitative information provided to the two organisations. However, the best agreement between reports to the two databases occurred from 2011 to 2013 , with close to $2,50,000$ pigs lost in 15 countries that reported to one or both of the databases during that period. Given that most pig herds are small, up to 50,000 households could have been affected by these losses. The DRC alone reported losses of about $1,50,000$ pigs from 2011 to 2013 , about $15 \%$ of its average pig population during the same period.

The socio-economic impact of the disease is felt in both newly and endemically infected countries. In sub-Saharan Africa, the effects of ASF are severe in the smallholder and traditional farming systems with poor biosecurity in which the majority of pigs are raised, where economic losses can have serious impacts on households that are already poor. The loss of a small number of pigs valued at only a few dollars can result in disruption of a child's education, as revenues from pigs are often use to cover school costs (Chenais, Boqvist, Sternberg-Lewerin, et al., 2017; Swai \& Lyimo, 2014). However, serious impacts on commercial farming operations in ECSA have also been reported (Chenais, Sternberg-Lewerin, et al., 2017; FAO, 2012c; Nana-Nukechap \& Gibbs, 1985; Penrith et al., 2013; Samui, Nambota, Mweene, \& Onuma, 1996; Swai \& Lyimo, 2014) and a quantitative survey in Uganda indicated that economic impact is aggravated with increasing herd size (Chenais, Boqvist, Emanuelson, et al., 2017).

Apart from the losses of pigs reported to the OIE and/or AUIBAR, few outbreaks have been documented, particularly in the ECSA countries. Available published and unpublished data on specific outbreaks are summarized in Table 2. Although control by stamping out is often not attempted in endemic countries, in several of the documented outbreaks the majority of pig deaths were due to compulsory slaughter.

The reported loss of $6,45,662$ pigs due to ASF in 19 ECSA countries in the decade from 2005-2014 amounts to less than $1 \%$ of the domestic pig population in the region. This can be attributed not only to under-reporting but also to the nature of the pig sector. In Africa, the socio-economic impact must be measured in the effect of the losses in low-income households and on small businesses that are unable to withstand shocks and are not covered by insurance. Even when it is possible to place a monetary value on the losses they may seem unimportant in global terms, but must be seen in the context of the poverty that prevails in most African countries, where keeping pigs can be a coping strategy for the poor. 


\section{3 | HISTORY, CURRENT STATUS, TRANSMISSION CYCLES, RECENT OUTBREAKS AND SOCIO- ECONOMIC IMPACT OF AFRICAN SWINE FEVER IN EASTERN, CENTRAL AND SOUTHERN AFRICA}

African swine fever is endemic in a sylvatic warthog-tick cycle and/ or in a domestic-tick or domestic pig cycle in the great majority of ECSA countries (Table 1). Sixteen ECSA countries reported ASF during the period 1996 to 2004 (Table 3) (OIE Handistatus II, http:// web.oie.int/hs2/report.asp), while 20 countries reported outbreaks during the period 2005 to 2016 (Table 4) (OIE-WAHIS, http://www. oie.int/en/animal-health-in-the-world/wahis-portal-animal-healthdata/). In most of the countries the status has changed very little. The majority reported repeated outbreaks or the endemic presence of infection in domestic pigs throughout the entire period. There are commonalities among the three sub-regions, particularly in terms of smallholder pig production systems and socio-economic impacts, but for clarity, the ASF situation in three sub-regions is described separately.
The long history of ASF in ECSA has resulted in a large body of research, much of it dating from the last century and most emanating from Eastern and Southern Africa, so that, with the exception of a few countries, the ASF situation is fairly well understood in these regions, particularly in terms of the sylvatic cycle. In Central Africa, research on ASF was undertaken in Angola in the 1950s and 1960s and in Cameroon in the 1980s and 1990s after its introduction in 1982. The interest has continued into the present century, inspired largely by advances in molecular genetic technology, as well as recognition of the potential importance of pig production.

\subsection{Eastern Africa}

\subsection{1 | History and current status}

African swine fever was first reported in pigs belonging to European settlers in Kenya in 1909, with the chief veterinary officer of the former German East Africa (consisting of present-day Burundi, Rwanda and mainland Tanzania) reporting two outbreaks that occurred in

\begin{tabular}{|c|c|c|c|c|c|c|c|c|c|}
\hline & 1996 & 1997 & 1998 & 1999 & 2000 & 2001 & 2002 & 2003 & 2004 \\
\hline \multicolumn{10}{|c|}{ East Africa } \\
\hline BUR & NR & NR & NR & NR & NR & + & NR & + & + \\
\hline ETH & - & - & - & - & - & - & - & - & - \\
\hline KEN & - & - & - & - & - & + & - & - & - \\
\hline MAD & - & - & + & + & + & + & + & + & + \\
\hline MAL & + & + & + & + & + & + & + & + & + \\
\hline MAU & - & - & - & - & - & - & - & - & - \\
\hline $\mathrm{MOZ}$ & + & + & + & + & + & + & + & + & + \\
\hline RWA & NR & NR & NR & NR & NR & NR & + & + & + \\
\hline TAN & - & - & - & - & - & + & + & + & + \\
\hline UGA & + & + & + & + & + & + & + & + & + \\
\hline ZAM & - & + & + & + & + & + & + & + & + \\
\hline ZIM & - & - & - & - & - & - & - & - & - \\
\hline \multicolumn{10}{|c|}{ Southern Africa } \\
\hline BOT & - & - & - & + & - & - & - & - & - \\
\hline NAM & - & + & + & - & - & + & - & - & + \\
\hline RSA & + & + & + & - & - & + & + & + & + \\
\hline \multicolumn{10}{|c|}{ Central Africa } \\
\hline ANG & + & + & + & + & + & + & + & + & + \\
\hline CAM & + & + & + & + & + & + & + & + & + \\
\hline CAR & - & NR & NR & NR & NR & NR & - & - & - \\
\hline $\mathrm{CHA}$ & - & - & - & - & - & - & - & - & - \\
\hline CGO & NR & NR & NR & NR & + & + & $?$ & + & NR \\
\hline DRC & NR & NR & + & NR & NR & + & + & + & + \\
\hline
\end{tabular}

TABLE 3 ASF outbreaks in ECSA countries during the period 1996-2004 according to OIE Handistatus II

Note. ANG: Angola; BOT: Botswana; BUR: Burundi; CAM: Cameroon; CAR: Central African Republic; CGO: Republic of Congo; CHA: Chad; DRC: Democratic Republic of Congo; ETH: Ethiopia; KEN: Kenya; MAD: Madagascar; MAL: Malawi; MAU: Mauritius; MOZ: Mozambique; NAM: Namibia; NR: not reported; RSA: South Africa; RWA: Rwanda; TAN: Tanzania; UGA: Uganda; ZAM: Zambia; ZIM: Zimbabwe. 
TA B LE 4 Outbreaks of ASF reported from 2005 - 2016 in East, Central and southern Africa (sources: OIE-WAHIS; AU-IBAR Animal Health Yearbooks/Animal Resources Yearbooks 2005 - 2014; peer-reviewed literature)

\begin{tabular}{|c|c|c|c|c|c|c|c|c|c|c|c|c|c|}
\hline Region \& Country & 2005 & 2006 & 2007 & 2008 & 2009 & 2010 & 2011 & 2012 & 2013 & 2014 & 2015 & 2016 & 2017 \\
\hline \multicolumn{14}{|l|}{ East Africa } \\
\hline BUR & + & NR & NR & + & + & + & NR & NR & NR & NR & + & + & + \\
\hline ETH & NR & NR & NR & NR & - & NR & + & $?$ & + & + & - & - & - \\
\hline KEN & - & + & + & - & - & + & + & + & - & - & + & + & - \\
\hline MAD & + & + & + & + & + & + & + & + & + & + & + & + & + \\
\hline MAL & + & + & + & + & + & + & + & + & + & NR & NR & NR & + \\
\hline MAU & - & - & + & - & - & - & - & - & - & - & - & - & - \\
\hline MOZ & + & + & + & + & + & + & + & + & + & + & - & + & + \\
\hline RWA & NR & + & + & + & + & + & + & + & + & + & NR & $?$ & + \\
\hline TAN & + & - & - & + & + & + & + & + & + & + & + & + & + \\
\hline UGA & + & + & + & + & + & + & + & NR & + & + & + & + & + \\
\hline ZAM & NR & + & + & + & + & + & + & + & + & + & NR & + & + \\
\hline ZIM & - & - & - & - & - & - & - & - & - & - & + & - & - \\
\hline \multicolumn{14}{|l|}{ Southern Africa } \\
\hline BOT & - & - & - & - & - & - & - & - & - & - & - & - & - \\
\hline NAM & + & - & - & + & + & + & + & + & + & + & - & + & + \\
\hline RSA & + & + & + & + & + & - & + & + & WH & + & WH & + & + \\
\hline \multicolumn{14}{|l|}{ Central Africa } \\
\hline ANG & + & + & + & + & + & + & + & + & + & + & + & - & - \\
\hline CAM & + & + & + & + & + & + & + & + & + & + & + & + & + \\
\hline CAR & - & - & - & - & $?$ & + & - & + & - & - & + & + & + \\
\hline $\mathrm{CHA}$ & - & - & - & - & - & + & + & + & - & + & + & + & - \\
\hline CGO & + & + & + & + & + & + & + & + & - & - & + & + & - \\
\hline DRC & + & + & + & + & + & + & + & + & + & + & + & + & - \\
\hline
\end{tabular}

Note. ANG: Angola; BOT: Botswana; BUR: Burundi; CAM: Cameroon; CAR: Central African Republic; CGO: Republic of Congo; CHA: Chad; DRC: Democratic Republic of Congo; ETH: Ethiopia; KEN: Kenya; MAD: Madagascar; MAL: Malawi; MAU: Mauritius; MOZ: Mozambique; NAM: Namibia; NR: not reported; RSA: South Africa; RWA: Rwanda; TAN: Tanzania; UGA: Uganda; WH: warthog; ZAM: Zambia; ZIM: Zimbabwe.

${ }^{a}$ http://www.oie.int/wahis_2/public/wahid.php/Diseaseinformation/statusdetail.

settlers' pigs in 1914 (Montgomery, 1921). Pig keeping was traditionally practised only in the western parts of Kenya, where it is likely that ASF did occur unreported in village pigs. However, a disease of pigs that differed clinically from classical swine fever was reported from the Eastern Province of Zambia in 1912 and 1914 (Wilkinson et al., 1988). There were also early reports of ASF in Malawi (Turnbull, 1932, 1933, 1934).

The corporate database of the Food and Agriculture Organization of the United Nations (FAOSTAT) indicates that four countries in the Eastern African region do not have pigs (Comoros including Mayotte, Djibouti, Eritrea and South Sudan). Seychelles, Somalia and the French island of Réunion have small pig populations and have never experienced ASF. All the remaining Eastern African countries have reported ASF, including two Indian Ocean island nations, Madagascar and Mauritius (Jori et al., 2013; Penrith et al., 2013). Zimbabwe has a relatively small pig population, with traditional and smallholder pig production largely confined to particular districts (Chiduwa, Chimonyo, Halimani, Chisambara, \& Dzama, 2008; Mashatise et al.,
2005). Only sporadic outbreaks of ASF have been reported (Table 1) and in 2015, Zimbabwe reported its first outbreak in domestic pigs since 1992 (Table 4) (van Heerden, Malan, Gadaga, \& Spargo, 2017). Madagascar and Mauritius reported ASF outbreaks for the first time in the last two decades and only Mauritius has succeeded in eradicating ASF (Table 1) (Lubisi, Dwarka, Meenowa, \& Jaumally, 2009). Kenya, Malawi, Mozambique, Tanzania, Uganda and Zambia have experienced multiple to frequent outbreaks (Table 3). The endemic occurrence of ASF in domestic pigs has subsequently been documented in several Eastern African countries: Kenya (Gallardo, Ademun, et al., 2011a; Gallardo, Okoth, et al., 2011c; Lichoti et al., 2016; Okoth et al., 2013), Madagascar (Randrianantoandro, Kono, \& Kubota, 2015; Ravaomanana et al., 2011, 2010; Roger, Ratovonjato, Vola, \& Uilenberg, 2001), Malawi (Haresnape, Lungu, \& Mamu, 1985, 1987); Mozambique (Penrith et al., 2007, 2004; Quembo et al., 2016), Tanzania (Misinzo et al., 2014; Wambura, Masambu, \& Msami, 2006), Uganda (Atuhaire, Afayoa, Ochwo, Mwesigwa, Okuni, et al., 2013; Barongo et al., 2015; Gallardo, Ademun, et al., 2011a; Muhangi 
et al., 2015; Muwonge et al.., 2012) and the Eastern Province of Zambia (Samui, Mwanaumo, \& Chizyuka, 1991; Samui et al., 1996; Simulundu et al., 2018, 2017; Wilkinson et al., 1988).

\subsection{2 | Transmission cycles and reported recent outbreaks}

The warthog-tick cycle has been demonstrated in Kenya, Malawi, Mozambique, Tanzania, Uganda, Zambia and Zimbabwe (Plowright et al., 1994; Quembo et al., 2016). Spill-over from the warthog-tick cycle to domestic pigs has been reliably reported from Kenya and Zimbabwe and is suspected to occur in areas where there is an interface between warthogs and domestic pigs in Mozambique, Tanzania, Uganda and Zambia (Kukielka et al., 2016; Quembo et al., 2016; Simulundu et al., 2017). Investigations in Malawi suggested that warthogs would play at best a minor role in ASF in domestic pigs because they were restricted to conservation areas distant from pig farming areas (Haresnape, Wilkinson, \& Mellor, 1988).

A pig-tick cycle was demonstrated to occur in Malawi in an area where no warthogs were present (Haresnape, Lungu, \& Mamu, 1985, 1987; Haresnape \& Mamu, 1986). Evidence for a similar cycle in Mozambique has recently been reported (Quembo et al., 2016). In many countries ASF is maintained in pig populations without involvement of warthogs or Ornithodoros ticks. In Zambia the virus circulates in pigs independently of warthogs and the occurrence of a pig-tick cycle has not been demonstrated (Simulundu et al., 2017; Wilkinson et al., 1988).

Effective separation of domestic pigs from warthogs by the use of biosecurity measures (i.e. double fencing of pig farms) resulted in no reports of ASF for more than 30 years in Kenya. In 1994 outbreaks of ASF occurred in piggeries, including small commercial farms, around Nairobi for the first time since 1963. The outbreaks could not be attributed to warthog contact and transport of infected pigs from Busia near the border with Uganda to an abattoir in Nairobi was the suspected source (M.L. Penrith, 1996, unpublished data). New information from research undertaken in the last decade has confirmed that ASF is endemic in some traditionally kept pig populations in western Kenya (Okoth et al., 2013; Thomas et al., 2016) and that transborder trade with Uganda is common (Lichoti et al., 2016; Nantima et al., 2016; Nantima, Ocaido, Ouma, et al., 2015). Like most areas with endemic circulation of ASFV in pigs, it is likely that low-level outbreaks are experienced frequently but occasional reports only reflect larger outbreaks and an absence of outbreaks in the intervening years is assumed, but is unlikely. Minor outbreaks may go unreported due to small herd size and relatively low mortality, as such populations are characterized by a high level of immunity, reflected by seropositivity and/or detection of virus in a varying but often high proportion of healthy pigs reported from Malawi, Mozambique, Tanzania and Uganda as well as western Kenya (Atuhaire, Afayoa, Ochwo, Mwesigwa, Mwiine, et al., 2013; Atuhaire et al., 2014; Haresnape, Lungu, \& Mamu, 1985, 1987; Penrith et al., 2004; Quembo et al., 2016; Thomas et al., 2016; Uttenthal et al., 2013).
Pig keeping is widespread in Uganda and outbreaks have been reported annually (Tables 3 and 4). It is thought that most of the outbreaks are pig-related, but that in some areas close to conservation areas involvement of warthogs or bushpigs may contribute (Chenais, Boqvist, Sternberg-Lewerin, et al., 2017; Dione et al., 2017; Kabuuka et al., 2014; Kukielka et al., 2016; Ståhl et al., 2014). The domestic cycle that prevails on the border with western Kenya is probably widespread in Uganda, with a far larger pig population than Kenya and ASF reported from multiple districts (Atuhaire, Afayoa, Ochwo, Mwesigwa, Mwiine, et al., 2013; Atuhaire, Ochwo, et al., 2013; Dione et al., 2017; Kabuuka et al., 2014).

Pig keeping has also increased in Tanzania and outbreaks have been reported in a number of districts, with some becoming widespread, apparently due to movement of pigs or infected pork that was fed as swill, but with possible wildlife involvement, for example in an outbreak that started in a town close to the Kilimanjaro National Park (Misinzo, Jumapili, et al., 2012; Misinzo, Kasanga, et al., 2012; Misinzo et al., 2014, 2011; Swai \& Lyimo, 2014; Wambura et al., 2006). Most of the outbreaks in Tanzania have been sporadic and of short duration, but a sustained outbreak with considerable spread to other areas occurred in Mbeya district in western Tanzania from 2010 to 2013, where earlier outbreaks had also been reported (Misinzo et al., 2014). These outbreaks were pig-related and links with neighbouring countries were suspected (Misinzo et al., 2014; Wambura et al., 2006).

The first outbreak outside the endemic area of the Eastern Province in Zambia was reported in 1989 on a single farm and was attributed to infected pork that originated in the Eastern Province (Samui et al., 1991). Subsequently, outbreaks have been experienced in most parts of the country and molecular genetic analysis could not confirm any links to the Eastern Province (Simulundu et al., 2017). Zimbabwe reported its first pig-related outbreak in 2015 close to the border with the endemic area in Mozambique (van Heerden et al., 2017).

The situation in Burundi and Rwanda, on the contrary, is very poorly documented by sporadic and recently more frequent reports to OIE over the last decade, but it would not be expected to differ greatly from that of neighbouring countries. Archived viruses from Burundi in 1984 and 1990 belonged to genotype X, one of the two p72 genotypes predominant in Kenya and Uganda (Bastos et al., 2003; Lubisi, Bastos, Dwarka, \& Vosloo, 2005). An outbreak of ASF in Kigoma, Tanzania, in 2004 was suspected to have resulted from the introduction of pigs from "a neighbouring country" into refugee camps close to the border with Burundi (OIE, 2004; Wambura et al., 2006).

Madagascar, Mauritius and Ethiopia have reported ASF for the first time in recent decades. Madagascar reported ASF for the first time in 1998 although mortality in pigs had started in 1997 and the disease has become endemic in domestic pigs (Costard, Porphyre, et al., 2009; Roger et al., 2001; Rousset et al., 2001). Mauritius reported ASF for the first time in October 2007 after some spread had already occurred and the disease was eradicated by the middle of 2008 after most of the island's pigs had died or been destroyed. The 
most likely source of the incursion into Mauritius was harbour waste fed to pigs as swill. Genotyping suggested that Madagascar was the probable country of origin (Lubisi et al., 2009).

Ethiopia reported an outbreak to AU-IBAR in 2011 (AU-IBAR, 2011), which was confirmed as ASF and further outbreaks were experienced in 2013 and 2014 (Achenbach et al., 2017). An archived report from Ethiopia to OIE in 2001 gave the date of the last outbreak of ASF as 1993, but no further information about that outbreak is available (ftp://ftp.oie.int/SAM/2001/ETH_A.pdf). This may be why Achenbach et al. (2017) referred to the 2011 outbreak in Ethiopia as the "first laboratory-confirmed outbreak" rather than the first outbreak. The pig sector in Ethiopia is small, although recently it has expanded (Tekle, Tesfay, \& Kifleyohannis, 2013), which may explain the paucity of earlier outbreaks. The source of infection was not determined and molecular characterization of outbreak viruses collected from 2011 to 2014 has revealed that they belong to two subtypes of a new p72 genotype designated Genotype XXIII, which is suggestive of possible warthog involvement (Achenbach et al., 2017).

\subsection{3 | Socio-economic impact}

Information on the economic impact of outbreaks is scarce (Table 2). Socio-economic effects of some outbreaks can be extrapolated from published information on the number of pigs lost. Outbreaks of ASF often affect a large number of households. The loss of $60 \%$ of the Madagascan pig population was reported after the introduction of the disease in 1998 (Rousset et al., 2001). The 2007 ASF incursion into Mauritius resulted in the loss of approximately $85 \%$ of the national herd, mainly due to the culling of around 13,000 pigs in order to eradicate the disease (Lubisi et al., 2009). In 2011, during an ASF outbreak in the Isoka District of Zambia, mortality was reported to be close to $100 \%$ and $46.7 \%$ of 84 households surveyed were directly affected. This corresponded to a reduction of $50 \%$ of the pig population in the district (Komba, Karimuribo, \& Kanemanema, 2014). Mortality of $84 \%$ was reported during the 2013 outbreak in Rombo District of Tanzania (Swai \& Lyimo, 2014). An outbreak in 2014 on a commercial farm in Uganda resulted in loss of the entire herd and had serious consequences for the manager and employees in terms of stress, depression and job losses (Chenais, SternbergLewerin, et al., 2017).

Perhaps the greatest impact of ASF in Eastern Africa has been beyond the borders of Africa. The virus introduced into the Republic of Georgia in 2007 and currently widespread in eastern Europe and China showed high similarity to the viruses isolated from outbreaks in Madagascar, Mozambique and Zambia, in particular viruses that had been isolated in Mozambique and Madagascar between 1998 and 2003 (Rowlands et al., 2008). That virus was also isolated from an incursion into Mauritius in 2007 (Lubisi et al., 2009) and subsequently from outbreaks in several districts in Tanzania since 2010 (Misinzo, Jumapili, et al., 2012; Misinzo, Kasanga, et al., 2012; Misinzo et al., 2014; Uttenthal et al., 2013) and an outbreak in Zimbabwe in 2015 that probably originated in Mozambique (van Heerden et al., 2017).

\section{2 | Central Africa}

\subsection{1 | History and current status}

The first report of ASF from Central Africa emanated from Angola in 1932 (Gago da Camara, 1933), although the virus from the Angolan outbreaks was only confirmed as ASF many years later (Mendes, 1994). Local breed pigs kept by the indigenous population of Angola were believed to be the reservoir of the virus (Mendes, 1971, 1994); no involvement of warthogs or other wild pigs has ever been reported and to our knowledge has not been investigated. Initiatives to develop a vaccine were undertaken at the veterinary laboratory in Angola even before the virus reached Europe (Mendes \& Daskalos, 1955), after efforts to produce pigs in the fertile central highlands to feed the Portuguese army were thwarted by outbreaks of ASF (Mendes, 1994).

With the exception of the historical information on Angola, revealing an endemic situation in domestic pigs that is supported by annual reporting of outbreaks to the OIE in recent decades, the ASF situation in Central Africa is less well documented (Table 1). Equatorial Guinea and Gabon have small pig populations and have never reported ASF. It has been reported that ASF was known to be present in DRC by 1939 (Saliki, Thiry, \& Pastoret, 1985). Reports from DRC to the OIE over the last decade and published information support endemic presence of the virus (Mulumba-Mfumu et al., 2017; OIE WAHIS, 2017). There have been sporadic reports to the OIE of ASF outbreaks in domestic pigs in the Republic of Congo over a long period (Tables 3 and 4).

The Central African island state of São Tomé e Principe suffered an incursion of ASF in 1979. The outbreak started amongst pigs that were fed swill from a military barracks that reportedly obtained pork from Angola (Sánchez-Botija, 1982) and resulted in the death or destruction of all the pigs on the island (Addah, 1988). Archived reports indicate that another introduction of ASF into a piggery in São Tomé e Principe had occurred in 1992 (Kouba, 2006; ftp://ftp.oie. int/SAM/2002/STP_F.pdf; ftp://ftp.oie.int/SAM/2003/STP_F.pdf).

Cameroon experienced its first outbreaks of ASF in 1982 and the disease became endemic in the major pig-producing areas in the west and south of Cameroon (Nana-Nukechap \& Gibbs, 1985).

\subsection{2 | Transmission cycles and reported recent outbreaks}

It is likely that the warthog-tick cycle occurs or historically occurred, in the DRC, but neither this nor the existence of a domestic pig-tick cycle have been adequately investigated. A survey carried out in the DRC for ticks infesting domestic pigs and Red River hogs (Potamochoerus porcus) found only uninfected hard ticks (L. Mulumba-Mfumu, 2015, unpublished data). However, the association between Ornithodoros species and warthogs has not been investigated. Although Ornithodoros ticks feed rapidly and drop off and are consequently seldom found on the host, in South Africa Ornithodoros nymphs have been found travelling on up to $50 \%$ of 
warthogs surveyed for ectoparasites (Boomker, Horak, Booyse, \& Meyer, 1991; Horak, Biggs, Hanssen, \& Hanssen, 1983; Horak, Boomker, De Vos, \& Potgieter, 1988; Jori et al., 2013) and a single nymph was found on a warthog in Central African Republic (CAR) (Uilenberg, Estrada-Peña, \& Thal, 2013).

In the Republic of Congo, a single record of ASFV infection in a warthog has been reported (Plowright et al., 1994) and an outbreak of ASF in domestic pigs in 2003 was attributed to spill-over from an outbreak on the other side of the border with DRC (ftp://ftp.oie. int/SAM/2003/COG_F.pdf.). Investigation of outbreaks in 2009 revealed ASF to be widespread in the Republic of Congo, with genotype I prevailing in the west and genotype IX present in the eastern districts (Gallardo, Ademun, et al., 2011a; Gallardo, Anchuelo, et al., 2011b).

Investigations failed to find evidence of the existence of a sylvatic cycle involving wildlife or ticks in Cameroon (Ekue \& Wilkinson, 1990). In 2010, an outbreak occurred in pigs in north-eastern Cameroon followed by immediate notifications of the first occurrence of ASF in CAR and Chad. ${ }^{1}$ The affected area was the Logone Basin, shared between Cameroon and Chad, where the human populations live in close proximity and keep free-ranging pigs in conditions of extremely low biosecurity (Assana et al., 2010; Koussou \& Duteurtre, 2002). Apart from earlier, apparently unconfirmed reports of ASF in Chad in 1983 (Plowright et al., 1994), there were no recent reports of ASF in Chad, north-eastern Cameroon or CAR, which shares a border with Chad. Recent reports describing the 2010 outbreak in Chad stated that this was the first time the country had experienced ASF (Ban-Bo, Idriss, \& Squarzoni, 2012; Bidjeh, Ban-Bo, \& Mopate Logtene, 2015). The reports on the 2010 outbreak in Chad concluded that a sylvatic cycle involving warthogs could be excluded as a source of infection, since the introduction could be traced with confidence to traded pigs known to have come from Cameroon. However, the authors indicated that further investigation should be undertaken to determine whether the sylvatic cycle might be present in Chad (Ban-Bo et al., 2012; Bidjeh et al., 2015).

\subsection{3 | Socio-economic impact}

The outbreaks of ASF in 2010 resulted in heavy losses in the Logone Basin (Bidjeh et al., 2015). Pig producers in these areas had previously benefited from the absence of ASF, which enabled pigs to be sold in urban Yaoundé (Koussou \& Duteurtre, 2002). Between 2010 and 2012 reports to AU-IBAR and OIE WAHIS reflected a loss of at least 43,905 pigs for the three countries if the lowest reported figures are accepted and 1,15,569 if the highest are used. The losses reported to OIE by Chad considerably exceeded the pig numbers reflected in the FAOSTAT corporate database for 2010, but this may not be surprising, as the number of pigs kept in the informal sector is difficult to compute.

${ }^{1}$ (http://www.oie.int/wahis_2/public/wahid.php/Reviewreport/Review/viewsummary? reportxml:xml:id=10059; http://www.oie.int/wahis_2/public/wahid.php/Reviewreport/ Review?reportxml:xml:id=20374).
Consequences of a large-scale commercial farm being put out of business by ASF in Kimwenza in the peri-urban area of Kinshasa, DRC included divorce and death due to loss of livelihoods by employees (DRC Central Veterinary Laboratory, unpublished report, 2010). In a survey on pig production conducted in the Kinshasa and Bas-Congo Provinces of DRC, 95\% of the farmers interviewed reported having experienced outbreaks of ASF (Kambashi et al., 2014).

The impact of ASF in Central Africa has also been felt beyond Africa. Molecular genetic characterization of the viruses that infected Portugal in 1957 and 1960 confirmed identity with viruses circulating in Angola, at that time an overseas department of Portugal (Bastos et al., 2003; Phologane, Bastos, \& Penrith, 2005). The impacts were felt not only in Europe, particularly the Iberian Peninsula, but also in the Caribbean and Brazil and efforts to eradicate it from the Italian island of Sardinia continue (Jurado et al., 2018).

\subsection{Southern Africa}

\subsection{1 | History and current status}

The discovery of "East African swine fever" in Kenya was followed by reports of a similar disease in pigs in north-eastern South Africa (De Kock et al., 1940; Steyn, 1928, 1932). The history of "swine fever" in South Africa dates back to the beginning of the 20th century, but whether the early outbreaks that occurred near the coast, more than $1,000 \mathrm{~km}$ from the ASF endemic area in the north-eastern part of the country, were classical swine fever imported from Europe or ASF cannot be determined (De Kock et al., 1940; Penrith, 2012). Until recently, reporting of ASF from Southern Africa has mainly involved isolated outbreaks involving single farms in Namibia and South Africa. Botswana has a small pig population and traditionally managed local breed pigs are found mainly around one village (Nsoso, Mannothoko, \& Modise, 2006). Outbreaks were reported in Botswana in 1953, 1987 and 1999, ascribed to probable warthog contact (Table 1). Recently the pattern in the sub-region has changed, with more reports of outbreaks involving spread amongst domestic pigs in Namibia and South Africa.

\subsection{2 | Transmission cycles and recent reported outbreaks}

Evidence of infection of warthogs and/or O. moubata complex ticks has been reported in Botswana, Namibia and South Africa (Plowright et al., 1994; Simpson \& Drager, 1979; Thomson, 1985; Thomson et al., 1983), with spill-over to domestic pigs confirmed or probable in outbreaks in all three countries. The absence of ASF from Eswatini is supported by a recent survey of Ornithodoros ticks from warthog burrows that did not detect infection in the ticks. Warthogs were not investigated, but the sampling frame used for the ticks was designed to detect an extremely low rate of infection (Boshoff, Bastos, Dube, $\&$ Heath, 2014). Lesotho is situated inside the free area in South 
Africa where warthogs are not infected and livestock production is dominated by ruminants, especially sheep.

Namibia has experienced sporadic, mainly warthog-related outbreaks since at least the 1920s (Plowright et al., 1994). Most of these outbreaks occurred on commercial cattle farms in the central parts of the country where a few pigs were being raised for domestic use under conditions of relatively low biosecurity and warthogs were present on the farm (Marruchella, Maseke, \& Scacchia, 2014; OIE WAHIS, 2017) However, since 2008 outbreaks have occurred in northern areas, some of them close to the border with Angola, in particular outbreaks in 2009 that appear to have taken longer than usual to control (OIE WAHIS, 2017).

In South Africa, an area in the north-eastern part of the country was demarcated as an ASF control area in 1935, on the basis of evidence of infection in warthogs and pig farmers within the control area have since that time been required by law to maintain separation from wild pigs by using double fencing around their farms (Magadla, Vosloo, Heath, \& Gummow, 2016). Sporadic outbreaks of ASF have occurred in the control area, with occasional spill-over to adjacent areas, but have never involved farms that complied with the legal requirements (Penrith \& Vosloo, 2009). Until 2012, the only outbreaks reported outside the control area occurred close to its border and could be traced back to the control area (OIE Handistatus II, 1996-2004, http://web.oie.int/hs2/sit_pays_mald pl.asp?c_pays=217\&c_mald=13; OIE WAHIS, 2017). However, an outbreak that started towards the end of 2011 due to pigs illegally moved from the control zone to an auction yard in the free zone was diagnosed in pigs presented for slaughter at an abattoir in the free area in early January 2012 (Geertsma, Mpofu, \& Walters, 2012). Limited spread had occurred in adjacent areas of two provinces and the outbreak was eradicated by modified stamping out with goodwill payments to the producers (Geertsma et al., 2012). In 2014, a limited outbreak occurred in the North West Province and the infected herd was culled, but since 2016 outbreaks have occurred in the North West, Free State and Northern Cape Provinces and investigations to determine the origin are ongoing (OIE WAHIS, 2017).

In contrast to the other sub-regions, smallholder pig farming has either been minimal or largely practised in areas where the sylvatic cycle is absent. This is changing, with smallholder pig farming being much more widely practised throughout South Africa and also in the northern parts of Namibia (Antwi \& Seahlodi, 2011; Fasina et al., 2015; Petrus et al., 2011; Veary \& Manoto, 2008). Risky trading practices involving regular sales of smallholder pigs from the ASF control area at auction facilities outside the control area have been described (Fasina et al., 2015). Informal trading and growing pig populations could result in the endemic establishment of ASF in domestic pigs. Areas that may require special attention are the northern border of Namibia with Angola, where people on both sides of the border who keep pigs have links to Angola and Lesotho, where the recent outbreaks in the Free State Province of South Africa in domestic pigs have brought the disease closer to the borders of Lesotho and vigilance will be required (http://www.oie.int/wahis_2/ public/wahid.php/Reviewreport/Review?reportxml:id=20374).

\subsection{3 | Socio-economic impact}

No published information about the socio-economic impacts of ASF outbreaks in Southern Africa was found. However, extrapolating from a classical swine fever outbreak that occurred in the Eastern Cape in 2004-2005 and resulted in the culling of almost half a million pigs, the effects of losing $95 \%$ of production on the smallholder farmers, in spite of better than market-related compensation, were reported to be devastating (Madzimure, Chimonyo, Zander, \& Dzama, 2013). Additionally, South Africa has a small but high value commercial pig sector for which an outbreak of ASF would be catastrophic.

\section{4 | KNOWLEDGE GAPS AND THE WAY FORWARD}

African swine fever is still a threat to pig production worldwide (Sánchez-Vizcaíno et al., 2013; Vergne et al., 2017); the situation has been aggravated by its recent arrival in China (Normile, 2018). Introductions to other parts of the world have ultimately originated in Africa and therefore managing ASF better at its source is imperative, not only to enable the full potential of pig production to improve nutrition and lift African families out of poverty, but also to protect the rest of the world.

The ability to manage a disease depends on knowledge of its epidemiology, capacity for rapid outbreak detection and diagnosis, biosecurity and an effective and affordable vaccine. Research on ASF in Eastern and Southern Africa historically focused strongly on the sylvatic cycle and on the biological characteristics of the virus (De Kock et al., 1940; DeTray, 1963; Montgomery, 1921; Peirce, 1974; Plowright \& Parker, 1967; Plowright, Parker, \& Peirce, 1969a, 1969b; Plowright et al., 1974; Plowright, Perry, \& Peirce, 1970; Plowright, Perry, Peirce, \& Parker, 1970; Thomson, 1985; Thomson et al., 1983). Recent research has continued to focus on both these aspects, using molecular genetic technology to further clarify the epidemiology and also to contribute to improved diagnostic tests and the continuing efforts to develop a vaccine (Bastos, Penrith, Macome, Pinto, \& Thomson, 2004; Bishop et al., 2015; Boshoff, Bastos, Gerber, \& Vosloo, 2007; Burrage, 2013; de Villiers et al., 2010; Lubisi et al., 2005; Lubisi, Bastos, Dwarka, \& Vosloo, 2007; Mulumba-Mfumu, Goatley, Saegerman, Takamatsu, \& Dixon, 2016; Phologane et al., 2005; Quembo et al., 2016, 2018; Simulundu et al., 2018; Simulundu et al., 2018; Souto et al., 2016). Molecular genetic information at least at p72 genotype level is available for most ECSA countries (Figure 1).

All the known p72 genotypes have been reported from the ECSA region. The highest numbers described to date have emanated from the area extending northwards between South Africa and Tanzania and eastwards to Zambia (Figure 1; Boshoff et al., 2007; Lubisi et al., 2005; Penrith, Bastos, Etter, \& Beltrán-Alcrudo, 2019). While a relationship between the intensity of research and the diversity of the viruses is likely, tapering off of the numbers to the north and west is probably real. Molecular epidemiology is of great value in tracing 
origins of and links between outbreaks and the knowledge based on p72 genotypes has been enhanced by studies using principally p54, p30 and/or the CVR variable region to demonstrate variation within the p72 genotypes (Gallardo, Ademun, et al., 2011a; Lubisi et al., 2007; Phologane et al., 2005; Simulundu et al., 2018). The incursions into other continents and into West Africa have involved genotype I and II viruses (Bastos et al., 2003; Rowlands et al., 2008).

Although ASF in Africa usually manifests as an acute severe disease, viruses of varying virulence occur naturally in Africa. Field strains of low to moderate virulence include a non-haemadsorbing virus from an outbreak in DRC (Thomson, Gainaru, \& Van Dellen, 1979), an outbreak virus in Angola (Nsalambi, 1993) and a moderately virulent tick isolate from South Africa (Souto et al., 2016). Since a level of resistance to the pathogenic effects of ASF exists in domestic pigs in several endemic areas in ECSA, virus-based studies will be necessary to determine or confirm variations in virulence. Based on a comparative analysis of $\mathrm{p} 72$ genotypes IX and $\mathrm{X}$ isolates in Kenya, it was suggested that further studies based on the observed differences in multicopy gene families might reveal a relationship to virulence (Bishop et al., 2015).

Whether or not a sylvatic cycle exists in the country, human behaviour appears to play the major role in maintenance and spread of ASF virus (Penrith \& Vosloo, 2009). Studies to determine risks for ASF maintenance and spread in domestic pig populations through farming practices, social networks and trade have been undertaken in a number of ECSA countries, with free-ranging husbandry, lack of biosecurity on farms and marketing of infected pigs and pork emerging as a recurring theme (Chenais, Boqvist, Emanuelson, et al., 2017; Chenais, Boqvist, Sternberg-Lewerin, et al., 2017; Chenais, Sternberg-Lewerin, et al., 2017; Costard, Porphyre, et al., 2009; Dione et al., 2017; FAO, 2012a; 2012b; Fasina et al., 2015; Kabuuka et al., 2014; Lichoti et al., 2016; Muhangi, Masembe, Berg, Ståhl, \& Ocaido, 2014; Nantima et al., 2016; Nantima, Ocaido, Ouma, et al., 2015; Okoth et al., 2013; Penrith et al., 2007; Penrith \& Vosloo, 2009; Randrianantoandro et al., 2015). Information about ASF in the ECSA countries that have experienced outbreaks is summarized in Table 1.

Many research teams around the world are attempting to address the lack of a vaccine for ASF (Arias et al., 2017; Rock, 2017). It is possible that a resource worth further investigation exists in the ECSA countries in the form of pig populations that have demonstrated a natural resistance to virulent ASF viruses. Greater resistance to the pathogenic effects of ASF virus in some populations of traditionally kept pigs has been investigated in Mozambique, Kenya and Uganda (Muhangi et al., 2015; Mujibi et al., 2018; Okoth et al., 2013; Penrith et al., 2004) and evidence for resistance based on healthy pigs with antibodies to ASF or lower than expected mortality has been reported in Angola, Malawi, Mozambique, Tanzania and Uganda (Allaway, Chinombo, Edelsten, Hutchings, \& Sumption, 1995; Atuhaire, Afayoa, Ochwo, Mwesigwa, Mwiine, et al., 2013; Atuhaire et al., 2014; Haresnape, Lungu, \& Mamu, 1985, 1987; Nsalambi, 1987; Penrith et al., 2004; Uttenthal et al., 2013). Obtaining and managing wild African suids for experimental studies is challenging, but genetic and immunological studies on domestic pigs from populations with demonstrated resistance could provide vital information for vaccine development.

Apart from the obvious problem of lack of a vaccine, a number of knowledge gaps have been identified (Table 5). In particular, the complex epidemiology of the disease in the ECSA countries, where all three cycles are involved, requires innovative approaches to control. There remain knowledge gaps of the major and minor drivers of disease and even concerning the precise geographic distribution of ASF.

Firstly, the precise area over which the warthog/Ornithodoros sylvatic cycle occurs has not been determined. The discovery that a new genotype caused the ASF outbreaks in Ethiopia is strongly suggestive of possible warthog involvement. Two species of warthogs occur in Ethiopia, the common warthog and the desert warthog (Phacochoerus aethiopicus) (d'Huart \& Grubb, 2001). The presence of O. moubata complex ticks in their burrows and their ASFV status need to be investigated. Whether or not a warthog/Ornithodoros cycle occurs in Angola, Burundi, CAR, Chad, Congo Republic, DRC and Rwanda needs to be determined.

Secondly, investigations into a possible role for bushpigs should continue, although currently available evidence suggests an incidental rather than a major role (Anderson, Hutchings, Mukarati, \& Wilkinson, 1998; Kukielka et al., 2016; Ståhl et al., 2014). These investigations should follow the example of previous investigations that focus on determining the level of contact between bushpigs and domestic pigs, because direct transmission of ASFV from bushpigs to domestic pigs has been demonstrated (Anderson et al., 1998), while any association between bushpigs and Ornithodoros ticks is unlikely (Jori \& Bastos, 2009; Jori et al., 2013). Thirdly, the existence of a domestic cycle between pigs and O. moubata complex ticks should be investigated in a number of countries in the region by using appropriate technology to collect and test ticks living in pig shelters (Jori et al., 2013).

Although investigations into the involvement of natural hosts and vectors are and will remain important, it is clear that the increase in number of countries affected and also in the number of outbreaks, greatly under-reported, is largely driven by human activities. A high proportion and in many countries the overwhelming majority of pigs, are kept in low biosecurity and free-ranging husbandry systems where disease control is minimal and difficult to implement. In the burgeoning peri-urban sector, swill feeding is commonly practised and particularly in countries where ASF is endemic, food waste that may contain pork poses a serious risk of ASF. Prohibition of swill feeding is not the solution to the problem because it is too difficult to monitor, but innovative ways to convert food waste into a safer and more nutritious feedstuff for pigs through processes of heating, drying and milling should be investigated (Roeder, 2011). Risk practices will only be modified or eliminated when the actors in the pig value chain are able to find viable alternatives to practices that pose a risk for spread of disease (Chenais, Boqvist, Sternberg-Lewerin, et al., 2017). 
TAB LE 5 Knowledge gaps and the way forward for better management of ASF in ECSA

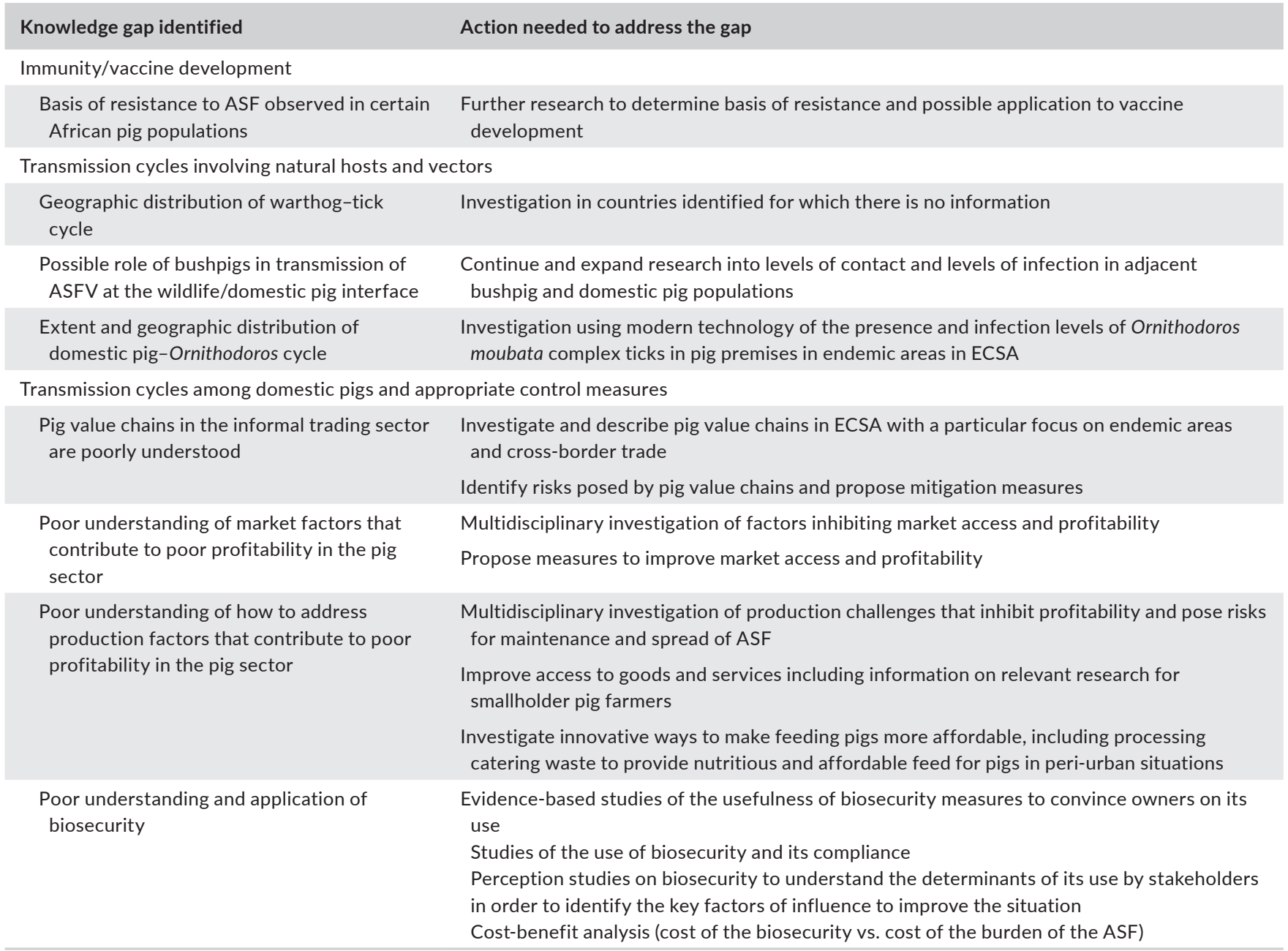

Therefore, from a point of view of control, the most important focus for research should be on pig value chains throughout subSaharan Africa. A study undertaken in Zambia demonstrated that mapping of ASF outbreaks and genetic characterization of the viruses that cause the outbreaks at sub-genotypic level could provide invaluable support for value chain studies by enabling outbreaks to be connected and patterns of spread determined (Simulundu et al., 2017). By identifying and mitigating the risks along value chains including during primary production a large reduction in the number of ASF outbreaks might be achieved. Furthermore, analysis of pig value chains is urgently needed in order to initiate changes where necessary to improve market incentives for pig producers, because the investment required to move from less biosecure to more biosecure production systems will only be made if the financial benefits are obvious and large enough to be attractive. The studies carried out by FAO in DRC and Kenya (FAO, 2012a; 2012b) emphasized the need to improve the infrastructure required to provide better market access and adequate slaughter hygiene, both of which are currently major problems in the sub-Saharan Africa pig sector in general. A study in South Africa also emphasized the need for better marketing infrastructure and information that is likely to be widespread (Antwi \& Seahlodi, 2011). Such studies need to be underpinned by more reliable information about the number of pigs being farmed in smallholder systems in ECSA countries. Examples exist in all three sub-regions. The classical swine fever incursion into the Eastern Cape Province of South Africa in 2005 culminated in the culling of 4,93,000 pigs (Akol \& Lubisi, 2014) in an area previously estimated to have a population of no more than 1,50,000 pigs ( $\mathrm{Dr}$ J. T. R. Robinson, 2016, personal communication). The pig population of Tanzania as reflected in FAOSTAT based on FAO estimates indicates a pig population of approximately half a million pigs from 2005 to 2014 , but a publication listing livestock numbers for Tanzania in 2014/2015 reported that there were 2.1 million pigs (Swai et al., 2015). A census carried out in Tanzania in 2007/2008 reported $1,581,396$ pigs (Government of Tanzania, 2012). The figures for pigs culled in Chad in 2010 reflected in OIE WAHIS were more than four times the total number of pigs in Chad according to FAOSTAT figures for 2010.

Finally, it must be accepted that poverty is one of the strongest drivers of risky practices in pig value chains because these practices are coping mechanisms for people who have little choice but to try to limit economic losses resulting from ASF. If better management 
of ASF is to be achieved, innovative approaches will need to be developed that will minimize the losses as well as the spread of ASF, as demonstrated in Uganda (Chenais, Boqvist, Emanuelson, et al., 2017; Chenais, Boqvist, Sternberg-Lewerin, et al., 2017).

\section{ACKNOWLEDGEMENTS}

LKD received funding from UK Biotechnology and Biological Sciences Research Council (BBSRC grant BBS/E/1/00007035. CM's ASF research is funded by a Wellcome Trust Fellowship (Grant 105684/Z/14/Z) and the African Union Commission (Grant AURG-II-1-196-2016).

\section{ORCID}

Claude Saegerman (iD https://orcid.org/0000-0001-9087-7436

Etienne Thiry (iD https://orcid.org/0000-0002-9585-7933

Mary Louise Penrith iD https://orcid.org/0000-0001-6924-4060

\section{REFERENCES}

Achenbach, J. E., Gallardo, C., Nieto-Pelegrín, E., Rivera-Arroyo, B., Degefa-Negi, T., Arias, M., ... Sánchez-Vizcaíno, J. M. (2017). Identification of a new genotype of African swine fever virus in domestic pigs from Ethiopia. Transboundary and Emerging Diseases, 64, 1393-1404. https://doi.org/10.1111/tbed.12511

Addah, L. (1988). Productivité du porc Large White à São Tomé e Principe. Revue D'élevage Et De Médecine Vétérinaire Des Pays Tropicaux, 41, 301-302.

Alders, R., Aognolo, A., Bagnol, B., De Bruyn, J., Kimboka, S., Kock, R., ... Young, M. (2014). Using a One Health approach to promote food and nutrition security in Tanzania and Zambia. Planet@Risk, 2, Special Issue on One Health (I/II), 187-190. Retrieved from http://www. planet-risk.org.

Alkhamis, M. A., Gallardo, C., Jurado, C., Soler, A., Arias, M., \& SánchezVizcaíno, J. M. (2018). Phylodynamics and evolutionary epidemiology of African swine fever p72-CVR genes in Eurasia and Africa. PLoS ONE, 13, e0192565. https://doi.org/10.1371/journal.pone.0192565

Allaway, E. C., Chinombo, D. O., Edelsten, R. M., Hutchings, G. H., \& Sumption, K. J. (1995). Serological study of pigs for antibody against African swine fever virus in two areas of southern Malawi. Revue Scientifique Et Technique, Office International Des Épizooties, 14, 667676. https://doi.org/10.20506/rst.14.3.864

Ampaire, A., \& Rothschild, M. F. (2010). Pigs, goats and chickens for rural development: small holder farmer's experience in Uganda. Livestock Research for Rural Development, 22. Retrieved from http://www. Irrd.org/Irrd22/6/ampa22102.htm.

Anderson, E. C., Hutchings, G. H., Mukarati, N., \& Wilkinson, P. J. (1998). African swine fever virus infection of the bushpig (Potamochoerus porcus) and its significance in the epidemiology of the disease. Veterinary Microbiology, 62, 1-15. https://doi.org/10.1016/ S0378-1135(98)00187-4

Antwi, M., \& Seahlodi, P. (2011). Marketing constraints facing emerging small-scale pig farmers in Gauteng Province, South Africa. Journal of Human Ecology, 36, 37-42. https://doi.org/10.1080/09709274.2011 .11906415

Arias, M., de la Torre, A., Dixon, L., Gallardo, C., Jori, F., Laddomada, A., ... Sanchez-Vizcaino, J.-M. (2017). Approaches and perspectives for development of African swine fever virus vaccines. Vaccines, 5, 35. https://doi.org/10.3390/vaccines5040035

Assana, E., Amadou, F., Thys, E., Lightowlers, M. W., Zoli, A. P., Dorny, P., \& Geerts, S. (2010). Pig-farming systems and porcine cysticercosis in northern Cameroon. Journal of Helminthology, 84, 441-446. https:// doi.org/10.1017/S0022149X10000167

Atuhaire, D. K., Afayoa, M., Ochwo, S., Mwesigwa, S., Mwiine, F. N., Okuni, J. B., ... Ojok, L. (2013). Prevalence of African swine fever virus in apparently healthy domestic pigs in Uganda. BMC Veterinary Research, 9, 263. https://doi.org/10.1186/1746-6148-9-263

Atuhaire, D. K., Afayoa, M., Ochwo, S., Mwesigwa, S., Okuni, J. B., Olaho-Mukani, W., \& Ojok, L. (2013). Molecular characterization and phylogenetic study of African swine fever isolates from recent outbreaks in Uganda (2010-2013). Virology Journal, 10, 247. https://doi. org/10.1186/1743-422X-10-247. Retrieved from http://www.virologyj.com/content/10/1/247.

Atuhaire, D. K., Ochwo, S., Afayoa, M., Mwesigwa, S., Mwiine, F. N., Okuni, J. B., ... Ojok, L. (2014). Molecular characterization of African swine fever virus in apparently healthy domestic pigs in Uganda. African Journal of Biotechnology, 13, 2491-2499. https://doi.org/10.5897/ AJB2014.13872

Atuhaire, D. K., Ochwo, S., Afayoa, M., Mwiine, F. N., Kokas, I., \& Arinaitwe, E., ... Ojok, L. (2013). Epidemiological overview of African swine fever in Uganda (2001-2012). Journal of Veterinary Medicine, 2013:939648. https://doi.org/10.1155/2013/939648

AU-IBAR. (2011). Panafrican Animal Health Yearbook 2011. Interafrican Bureau for Animal Resources: Nairobi.

Ban-Bo, B. A., Idriss, O. A., \& Squarzoni, C. D. (2012). Controle de peste porcine africaine (PPA) dans les elevages traditionnels au Tchad. Journal of Animal and Plant Sciences, 15, 2261-2266. Retrieved from http://www.m.elewa.org/JAPS.

Barongo, M. B., Ståhl, K., Bett, B., Bishop, R. P., Fèvre, E. M., Aliro, T., ... Ssematimba, A. (2015). Estimating the basic reproductive number (R0) for African swine fever virus (ASFV) transmission between pig herds in Uganda. PLoS ONE, 10, 0125842. https://doi.org/10.1371/ journal.pone. 0125842

Bastos, A. D., Penrith, M. L., Crucière, C., Edrich, J. L., Hutchings, G., Roger, F., ... Thomson, G. R. (2003). Genotyping field strains of African swine fever virus by partial p72 gene characterisation. Archives of Virology, 148, 693-706. https://doi.org/10.1007/ s00705-002-0946-8

Bastos, A. D. S., Penrith, M. L., Macome, F., Pinto, F., \& Thomson, G. R. (2004). Co-circulation of two genetically distinct viruses in an outbreak of African swine fever in Mozambique: No evidence for individual infection. Veterinary Microbiology, 103, 169-182. https://doi. org/10.1016/j.vetmic.2004.09.003

Bidjeh, K., Ban-Bo, B. A., \& Mopate Logtene, Y. (2015). Factors contributing to the introduction and the spread of African swine fever in Chad. International Journal of Current Microbiology and Applied Sciences, 4, 607-313. Retrieved from http://www.ijcmas.com.

Bishop, R. P., Fleischauer, C., de Villiers, E. P., Okoth, E. A., Arias, M., Gallardo, C., \& Upton, C. (2015). Comparative analysis of the complete genome sequences of Kenyan African swine fever isolates within p72 genotypes IX and X. Virus Genes, 50, 303-309. https:// doi.org/10.1007/s11262-014-1156-7

Boomker, J., Horak, I. G., Booyse, D. G., \& Meyer, S. (1991). Parasites of South African wildlife. VIII. Helminth and arthropod parasites of warthogs, Phacochoerus aethiopicus, in the Eastern Transvaal. Onderstepoort Journal of Veterinary Research, 58, 195-202.

Boshoff, C. I., Bastos, A. D. S., Dube, M. M., \& Heath, L. (2014). First molecular assessment of the African swine fever virus status of Ornithodoros ticks from Swaziland. Onderstepoort Journal of Veterinary Research, 81: E1-5. https://doi.org/10.4102/ojvr. v81i1.846. 
Boshoff, C. I., Bastos, A. D. S., Gerber, L. J., \& Vosloo, W. (2007). Genetic characterisation of African swine fever viruses from outbreaks in southern Africa (1973-1999). Veterinary Microbiology, 121, 45-55. https://doi.org/10.1016/j.vetmic.2006.11.007

Brown, A. A., Penrith, M. L., Fasina, F. O., \& Beltran-Alcrudo, D. (2018). The African swine fever epidemic in West Africa, 1996-2002. Transboundary and Emerging Diseases, 65, 64-76. https://doi. org/10.1111/tbed.12673

Burrage, T. G. (2013). African swine fever virus infection in Ornithodoros ticks. Virus Research, 173, 131-139. https://doi.org/10.1016/j. virusres.2012.10.010

Chenais, E., Boqvist, S., Emanuelson, U., von Brömssen, C., Ouma, E., Aliro, T., ... Sternberg-Lewerin, S. (2017). Quantitative assessment of social and economic impact of African swine fever outbreaks in Northern Uganda. Preventive Veterinary Medicine, 144, 134-148. https://doi.org/10.1016/j.prevetmed.2017.06.002

Chenais, E., Boqvist, S., Sternberg-Lewerin, S., Emanuelson, U., Ouma, E., \& Dione, M., ... Ståhl, K. (2017). Knowledge, attitudes and practices related to African swine fever within smallholder pig production in northern Uganda. Transboundary and Emerging Diseases, 64, 105-115. https://doi.org/10.1111/tbed.12347

Chenais, E., Sternberg-Lewerin, S., Boqvist, S., Emanuelson, U., Aliro, T., Tejler, E., ... Ståhl, K. (2015). African swine fever in Uganda: Qualitative evaluation of three surveillance methods with implications for other resource-poor settings. Frontiers in Veterinary Science, 2, 51. https://doi.org/10.3389/fvets.2015.00051

Chenais, E., Sternberg-Lewerin, S., Boqvist, S., Liu, L., LeBlanc, N., Aliro, T., ... Ståhl, K. (2017). African swine fever outbreak on a mediumsized farm in Uganda: Biosecurity breaches and within-farm virus contamination. Tropical Animal Health and Production, 49, 337-346. https://doi.org/10.1007/s11250-016-1197-0

Chiduwa, G., Chimonyo, M., Halimani, T. E., Chisambara, S. R., \& Dzama, K. (2008). Herd dynamics and contribution of indigenous pigs to the livelihoods of rural farmers in a semi-arid area of Zimbabwe. Tropical Animal Health and Production, 40, 125-136. https://doi.org/10.1007/ s11250-007-9071-8

Costard, S., Porphyre, V., Messad, S., Rakotondrahanta, S., Vidon, H., Roger, F., \& Pfeiffer, D. U. (2009). Multivariate analysis of management and biosecurity practices in smallholder farms in Madagascar. Preventive Veterinary Medicine, 92, 199-209. https://doi. org/10.1016/j.prevetmed.2009.08.010

Costard, S., Wieland, B., de Glanville, W., Jori, F., Rowlands, R., Vosloo, W., ... Dixon, L. K. (2009). African swine fever: How can global spread be prevented? Philosophical Transactions of the Royal Society B, 364, 2683-2696. https://doi.org/10.1098/rstb.2009.0098

d'Huart, J. P., \& Grubb, P. (2001). Distribution of the common warthog (Phacochoerus africanus) and the desert warthog (Phacochoerus aethiopicus) in the Horn of Africa. African Journal of Ecology, 39, 156-169. https://doi.org/10.1046/j.0141-6707.2000.00298.x

de Abreu, E. F., Valadão, F. B., Limpo Serra, J. J. B., Ornelas Mário, R., \& Sousa Montenegro, A. (1962). Peste suína africana em Moçambique. Anais Dos Serviços Veterinárias De Moçambique, 8, 105-123.

De Kock, G., Robinson, E. M., \& Keppel, J. J. G. (1940). Swine fever in South Africa. Onderstepoort Journal of Veterinary Science and Animal Industry, 14, 31-93.

de Villiers, E. P., Gallardo, C., Arias, M., da Silva, M., Upton, C., Martin R., \& Bishop, R. P. (2010). Phylogenomic analysis of 11 complete African swine fever virus genome sequences. Virology, 400, 128-136. https://doi.org/10.1016/j.virol.2010.01.019

DeTray, D. E. (1963). African swine fever. Advances in Veterinary Science and Comparative Medicine, 8, 299-333.

Dione, M. M., Akol, J., Roesel, K., Kunga, J., Ouma, E. A., Wieland, B., \& Pezo, D. (2017). Risk factors for African swine fever in smallholder pig production systems in Uganda. Transboundary and Emerging Diseases, 64, 872-882. https://doi.org/10.1111/tbed.12452
Dixon, L. K., Alonso, C., Escribano, J. M., Martins, C., Revilla, Y., Salas, M., \& Takamatsu, H. (2005). Asfarviridae. In King, A. M. Q., Adams, M. J., Carstens, E. B., \& Lefkowitz, E. J. (Eds.), Virus Taxonomy. Classification and Nomenclature of Viruses. Ninth Report of the International Committee on Taxonomy of Viruses (pp. 154-163). Amsterdam, the Netherlands: Elsevier/Academic Press.

Ekue, N. F., \& Wilkinson, P. J. (1990). Absence of Ornithodoros moubata, the vector of African swine fever virus, from the main pig producing area of Cameroon. Tropical Animal Health and Production, 22, 127131. https://doi.org/10.1007/BF02239840

FAO. (Ed.) (2012a). Secteur porcine République Démocratique du Congo. Revues nationales de l'élevage de la division de la production et de la santé animales de la FAO, No. 2, Rome, Food and Agriculture Organization of the. United Nations.

FAO. (Ed.) (2012b). Pig sector Kenya. FAO Animal Production and Health Livestock Country Reviews, No. 3, Rome, Food and Agriculture Organization of the. United Nations.

FAO. (Ed.) (2012c). African swine fever (ASF) Recent developments and timely updates - worrisome dynamics. Steady spread towards unaffected areas could have disastrous impact. In Focus on..., No. 6 [electronic bulletin]. Rome, Food and Agriculture Organization of the United Nations. Retrieved from http://www.fao.org/docrep/016/ ap372e/ap372e.pdf

Fasina, F. O., Mokoele, J. M., Spencer, B. T., van Leengoed, L. A. M. L., Bevis, Y., \& Booysen, I. (2015). Spatio-temporal patterns and movement analysis of pigs from smallholder farms and implications for African swine fever spread, Limpopo province, South Africa. Onderstepoort Journal of Veterinary Research. 82:795. https://doi. org/10.4102/opjr.v82i1.795

Gago da Câmara, N. J. (1933). História da peste suína em Angola. Pecuária: Anais Dos Serviços Pecuários Da Colónia De Angola 1932, 1, 25-40.

Gallardo, C., Ademun, A. R., Nieto, R., Nantima, N., Arias, M., Martín, E., ... Bishop, R. P. (2011a). Genotyping of African swine fever virus (ASFV) isolates associated with disease outbreaks in Uganda in 2007. African Journal of Biotechnology, 10, 3488-3497. https://doi.org/10.5897/ AJB10.1439

Gallardo, C., Anchuelo, R., Pelayo, V., Poudevigne, F., Tati, L., Nzoussi, J., ... Arias, M. (2011b). African swine fever virus p72 genotype IX in domestic pigs, Congo, 2009. Emerging Infectious Diseases, 17, 15561558. https://doi.org/10.3201/eid1708.101877

Gallardo, C., Okoth, E., Pelayo, V., Anchuelo, R., Martin, E., Simon, A., ... Bishop, R. P. (2011c). African swine fever viruses with two different genotypes, both of which occur in domestic pigs, are associated with ticks and adult warthogs, respectively, at a single geographical site. Journal of General Virology, 92:432-444. https://doi.org/10.1099/ vir.0.025874-0

Geertsma, P. J., Mpofu, D., \& Walters, J. (2012). Investigation and control of an outbreak of African swine fever in the Gauteng Province in 2012. Proceedings of the $10^{\text {th }}$ Annual Congress of the Southern African Society for Veterinary Epidemiology and Preventive Medicine, 1-3 August 2012, Farm Inn, South Africa, pp. 17-21.

Glass, N., Perrin, N. A., Kohli, A., \& Remy, M. M. (2014). Livestock/animal assets buffer the impact of conflict-related traumatic events on mental health symptoms for rural women. PLoS ONE. 9:e111708. https:// doi.org/10.1371/journal.pone.0111708

Government of Tanzania. (2012). National sample census of agriculture, Small holder agriculture, Volume III: Livestock Sector - National Report. Ministry of Agriculture, Food Security and Cooperatives, Ministry of Livestock Development and Fisheries, Ministry of Water and Irrigation, Ministry of Agriculture, Livestock and Environment, Zanzibar, Prime Minister's Office, Regional Administration and Local Governments, Ministry of Industries, Trade and Marketing, The National Bureau of Statistics and the Office of the Chief Government Statistician, Zanzibar. Retrieved from http://www. kilimo.go.tz/agricultural\%20statistics/web/Nationa\%20sample\%20 
census $\% 20$ of $\% 20$ Agriculture $\% 20200708 \% 20$ vol.\%20111/ FINAL\%20LIVESTOCK-\%20NATIONAL\%20Final\%20Draft\%20 10\%20March\%202012.pdf.

Halimani, T. E., Muchadeyi, F. C., Chimonyo, M., \& Dzama, K. (2012). Opportunities for conservation and utilisation of local pig breeds in low-input production systems in Zimbabwe and South Africa. Tropical Animal Health and Production, 45:81-90. https://doi.org/10.1007/ s11250-012-0177-2

Haresnape, J. M., Lungu, S. A. M., \& Mamu, F. D. (1985). A four-year survey of African swine fever in Malawi. Journal of Hygiene, 95:309-323. https://doi.org/10.1017/S0022172400062732

Haresnape, J. M., Lungu, S. A. M., \& Mamu, F. D. (1987). An updated survey of African swine fever in Malawi. Epidemiology and Infection, 99:723-732. https://doi.org/10.1017/S0950268800066589

Haresnape, J., \& Mamu, F. D. (1986). The distribution of ticks of the Ornithodoros moubata complex (Ixodoidea: Argasidae) in Malawi, and its relation to African swine fever epizootiology. Journal of Hygiene, 96:535-544. https://doi.org/10.1017/S0022172400066341

Haresnape, J. M., Wilkinson, P. J., \& Mellor, P. S. (1988). Isolation of African swine fever virus from ticks of the Ornithodoros moubata complex (Ixodoidea: Argasidae) collected within the African swine fever enzootic area of Malawi. Epidemiology and Infection, 101:173185. https://doi.org/10.1017/S0950268800029332

Horak, I. G., Biggs, H. C., Hanssen, T. E., \& Hanssen, R. E. (1983). The prevalence of helminth and arthropod parasites of warthog, Phacochoerus aethiopicus, in South West Africa/Namibia. Onderstepoort Journal of Veterinary Research, 50:145-148.

Horak, I. G., Boomker, J., De Vos, V., \& Potgieter, F. T. (1988). Parasites of domestic and wild animals in South Africa. XXIII. Helminth and arthropod parasites of warthogs, Phacochoerus aethiopicus, in the Eastern Transvaal Lowveld. Onderstepoort Journal of Veterinary Research, 55:145-152.

Jori, F., \& Bastos, A. D. S. (2009). Role of wild suids in the epidemiology of African swine fever. EcoHealth, 6:296-310. https://doi.org/10.1007/ s10393-009-0248-7

Jori, F., Vial, L., Penrith, M. L., Pérez-Sánchez, R., Etter, E., Albina, E., ... Roger, F. (2013). Review of the sylvatic cycle of African swine fever in sub-Saharan Africa and the Indian ocean. Virus Research, 173:212227. https://doi.org/10.1016/j.virusres.2012.10.005

Jurado, C., Fernández-Carrión, E., Mur, L., Rolesu, S., Laddomada, A., \& Sánchez-Vizcaíno, J. M. (2018). Why is Africa swine fever still present in Sardinia? Transboundary and Emerging Diseases, 65:557-566. https://doi.org/10.1111/tbed.12740

Kabuuka, T., Kasaija, P. D., Mulindwa, H., Shittu, A., Bastos, A. D. S., \& Fasina, F. O. (2014). Drivers and risk factors for circulating African swine fever virus in Uganda, 2012-2013. Research in Veterinary Science, 97:218-225. https://doi.org/10.1016/j.rvsc.2014.07.001

Kamaghe, A. A. S., Mlozi, M. R. S., Mejer, H., \& Johansen, M. V. (2014). Assessment of livelihoods of smallholder pig keepers in Mbeya Rural and Mbozi Districts, Mbeya Region, Tanzania. International Journal of Agricultural Science Research, 3:260-267.

Kambashi, B., Picron, P., Boudry, C., Théwis, A., Kiatoko, H., \& Bindelle, J. (2014). Smallholder pig production systems along a periurban-rura gradient in the Western Provinces of the Democratic Republic of Congo. Journal of Agriculture and Rural Development in the Tropics and Subtropics, 115:9-22.

Komba, E. V. G., Karimuribo, E. D., \& Kanemanema, M. C. (2014). Socioeconomic impact of African swine fever outbreak of 2011 and its epidemiology in Isoka District of Zambia. Tanzania Veterinary Journal. 29: 39 -47 http://www.ajol.info/index.php/tvj/article/view/110205

Kouba, V. (2006). Global table of epizootiological importance: Reported cases of disease/pathogen introduction in individual countries - according to specific diseases. Retrieved from http://vaclavkouba.byl. cz/disintrod.htm.
Koussou, M. O., \& Duteurtre, G. (2002). Les facteurs de competitivité de la filière porcine dans la Bassin du Logone. Koussou_Duteurtre_2002.pdf. Retrieved from http://pigtrop. cirad.fr/subjects/socio_economy_in_pig_production_sector/ filiere_porcine_au_nord_cameroun.

Kukielka, E. A., Jori, F., Martínez-López, B., Chenais, E., Masembe, C., Chavernac, D., \& Ståhl, K. (2016). Wild and domestic pig interactions at the wildlife-livestock interface of Murchison Falls National Park, Uganda, and the potential association with African swine fever outbreaks. Frontiers in Veterinary Science. 3:31. https://doi.org/10.3389/ fvets.2016.00031

Lichoti, J. K., Davies, J., Kitala, P. M., Githigia, S. M., Okoth, E., Maru, Y., ... Bishop, R. P. (2016). Social network analysis provides insights into African swine fever epidemiology. Preventive Veterinary Medicine, 126:1-10. https://doi.org/10.1016/j.prevetmed.2016.01.019

Lubisi, B. A., Bastos, A. D. S., Dwarka, R. M., \& Vosloo, W. (2005). Molecular epidemiology of African swine fever in East Africa. Archives of Virology, 150:2439-2452. https://doi.org/10.1007/ s00705-005-0602-1

Lubisi, B. A., Bastos, A. D. S., Dwarka, R. M., \& Vosloo, W. (2007). Intragenotypic resolution of African swine fever viruses from an East African domestic pig cycle: A combined $p 72-C V R$ approach. Virus Genes, 35:729-735. https://doi.org/10.1007/ss11262-007-0148-2

Lubisi, B. A., Dwarka, R. M., Meenowa, D., \& Jaumally, R. (2009). An investigation into the first outbreak of African swine fever in the Republic of Mauritius. Transboundary and Emerging Diseases, 56:178188. https://doi.org/10.1111/j.1865-1682.2009.01078.x

Madzimure, J., Chimonyo, M., Zander, K. K., \& Dzama, K. (2013). Potential for using indigenous pigs in subsistence-oriented and market-oriented small-scale farming systems of Southern Africa. Tropical Animal Health and Production, 45:135-142. https://doi.org/10.1007/ s11250-012-0184-3

Magadla, N. R., Vosloo, W., Heath, L., \& Gummow, B. (2016). The African swine fever control zone in South Africa and its current relevance. Onderstepoort Journal of Veterinary Research, 83:a1034. https://doi. org/10.4102/ojvr.v83i1.1034

Marruchella, G., Maseke, M., \& Scacchia, M. (2014). Quando la peste suina africana gioca in casa - descrizione di un focolaio in Namibia. Large Animal Review. 20:249-251.

Mashatise, E., Hamudikuwanda, H., Dzama, K., Chimonyo, M., \& Kanengoni, A. (2005). Socio-economic roles, traditional management systems and reproductive patterns of Mukota pigs semi-arid north-eastern Zimbabwe. Bunda Journal of Agriculture, Environmental Science and Technology, 3:97-105.

Mendes, A. M. (1971). Algumas doenças dos animais em Angola e Moçambique e sua importância na higiene das carnes. Revista Portuguesa De Ciencias Veterinárias, 66:271-286.

Mendes, A. M. (1994). A história da peste suína africana em Angola. Revista Portuguesa De Ciências Veterinárias. 89:110-120.

Mendes, A. M., \& Daskalos, A. M. (1955). Studies on the lapinization of African swine fever virus in Angola. Bulletin of Epizootic Diseases of Africa. 3:9-14.

Michaud, V., Randriamparany, T., \& Albina, E. (2013). Comprehensive phylogenetic reconstructions of African swine fever virus: Proposal for a new classification and molecular dating of the virus. PLOS ONE. 8:e69662. https://doi.org/10.1371/journal.pone.0069662

Misinzo, G., Jumapili, F., Ludosha, M., Mafie, E., Silialis, J., Mushi, R., ... Van Doorsselaere, J. (2012). Genotyping of African swine fever virus from an outbreak in Tanzania in 2009. Research Opinions in Animal and Veterinary Sciences. 2:334-338.

Misinzo, G., Kasanga, C. J., Mpelumbe-Ngeleja, C., Masambu, J., Kitambi, A., \& Van Doorsselaere, J. (2012). African swine fever virus, Tanzania, 2010-2012. Emerging Infectious Diseases. 18:2081-2083. https://doi. org/10.3201/eid1812.121083 
Misinzo, G., Kwavi, D. E., Sikombe, C. D., Makange, M., Peter, E., Muhairwa, A. P., \& Madege, M. J. (2014). Molecular characterization of African swine fever virus from domestic pigs in northern Tanzania during an outbreak in 2013. Tropical Animal Health and Production. 46:1199-1207. https://doi.org/10.1007/ s11250-014-0628-z

Misinzo, G., Magambo, J., Masambu, J., Yongolo, M. G., Van Doorsselaere, J., \& Nauwynck, H. J. (2011). Genetic characterization of African swine fever viruses from a 2008 outbreak in Tanzania. Transboundary and Emerging Diseases. 58:86-92. https:// doi.org/10.1111/j.1865-1682.2010.01177.x

Montgomery, R. E. (1921). On a form of swine fever occurring in British East Africa (Kenya Colony). Journal of Comparative Pathology. 34(159-191):243-262.

Muhangi, D., Masembe, C., Berg, M., Ståhl, K., \& Ocaido, M. (2014). Practices in the pig value chain in Uganda: Implications to African swine fever transmission. Livestock Research for Rural Development, 26:5. http://www.Irrd.org/Irrd/26/5/muha26094.html.

Muhangi, D., Masembe, C., Emanuelson, U., Boqvist, S., Mayega, L., Ademun, R. O., ... Ståhl, K. (2015). A longitudinal survey of African swine fever in Uganda reveals high apparent disease incidence rates in domestic pigs, but absence of detectable persistent virus infections in blood and serum. BMC Veterinary Research. 11:106. https:// doi.org/10.1186/s12917-015-0426-5

Mujibi, F. D., Okoth, E., Cheruiyot, E. K., Onzere, C., Bishop, R. P., Fèvre, E. M., ... Rothschild, M. (2018). Genetic diversity, breed composition and admixture of Kenyan domestic pigs. PLoS ONE. 13:e0190080. https://doi.org/10.1371/jounral.pone.0190080

Mulumba-Mfumu, L., Achenbach, J., Mauldin, M., Dixon, L., Tshilenge, C., Thiry, E., ... Diallo, A. (2017). Genetic assessment of African swine fever isolates involved in outbreaks in the Democratic Republic of Congo between 2005 and 2012 reveals co-circulation of p72 genotypes I, IX and XIV, including 19 variants. Viruses. 9:31. https://doi. org/10.3390/v9020031

Mulumba-Mfumu, L. K., Goatley, L. C., Saegerman, C., Takamatsu, H.-H., \& Dixon, L. K. (2016). Immunization of African indigenous pigs with attenuated genotype I African swine fever virus OURT88/3 induces protection against challenge with virulent strains of genotype I. Transboundary and Emerging Diseases. 63:e323-e327. https://doi. org/10.1111/tbed.12303

Mutua, F., Dewey, C., \& Schelling, E. (2010). Farmer perceptions on indigenous pig farming in Kakamega District, Western Kenya. Nordic Journal of African Studies. 19:43-57.

Muwonge, A., Munang'andu, H. M., Kankya, C., Biffa, D., Oura, C., Skjerve, E., \& Oloya, J. (2012). African swine fever among slaughtered pigs in Mubende district, Uganda. Tropical Animal Health and Production. 44:1593-1598. https://doi.org/10.1007/s11250-012-0112-6

Nana-Nukechap, M. F., \& Gibbs, E. P. J. (1985). Socioeconomic effects of African swine fever in Cameroon. Tropical Animal Health and Production. 17:183-184. https://doi.org/10.1007/BF02356970

Nantima, N., Davies, J., Dione, M., Ocaido, M., Okoth, E., Mugisha, A., \& Bishop, R. (2016). Enhancing knowledge and awareness of biosecurity practices among smallholder pig farmers in four districts along the Kenya - Uganda border. Tropical Animal Health and Production. 48:727-734. https://doi.org/10.1007/s11250-016-1015-8

Nantima, N., Ocaido, M., Davies, J., Dione, M., Okoth, E., Mugisha, A., \& Bishop, R. (2015). Characterization of smallholder pig production systems in four districts along the Uganda-Kenya border. Livestock Research for Rural Development. 27:8. http://www.Irrd.org/Irrd27/8/ nant27166.html.

Nantima, N., Ocaido, M., Ouma, E., Davies, J., Dione, M., Okoth, E., ... Bishop, R. (2015). Risk factors associated with occurrence of African swine fever outbreaks in smallholder pig farms in four districts along the Uganda-Kenya border. Tropical Animal Health and Production. 47:589-595. https://doi.org/10.1007/s11250-015-0768-9
Normile, D. (2018). Arrival of deadly pig disease could spell disaster for China. Science. 361:741. Retrieved from http://science.sciencemag. org/.

Nsalambi, D. (1987). Particularidades da epizootiologia, do quadro clinico e da patomorfologia da peste suina africana na Republica Popular de Angola. Doctoral thesis, Academy of Sciences of. Ukraine, Kiev.

Nsalambi, D. (1993). Differences cliniques et anatomopathologiques de deux souches du virus de la peste porcine africaine (ppa) en Angola. Revue D'élevage Et De Medecine Vétérinaire Des Pays Tropicaux. 46:539-543.

Nsoso, S. J., Mannothoko, G. G., \& Modise, K. (2006). Monitoring production, health and marketing of indigenous Tswana pigs in Ramotswa village of Botswana. Livestock Research for Rural Development. 18:9. Retrieved from http://www.Irrd.org//rrd18/9/nsos18125.hml.

OIE. (2004). African swine fever in Tanzania - Follow-up report No. 2. Disease. Information. 17(7):116-117.

OIE WAHIS. (2017). WAHIS Portal: Animal Health Data. Retrieved from http://www.oie.int/en/animal-health-in-the-world/wahis-portalanimal-health-data/.

Okoth, E., Gallardo, C., Macharia, J. M., Omore, A., Pelayo, V., Bulimo, D. W., ... Bishop, R. P. (2013). Comparison of African swine fever virus prevalence and risk in two contrasting pig-farming systems in Southwest and Central Kenya. Preventive Veterinary Medicine. 110:198205. https://doi.org/10.1016/j.prevetmed.2012.11.012

Ouma, E., Dione, M., Lule, P., Roesel, K., \& Pezo, D. (2014). Characterization of smallholder pig production systems in Uganda: Constraints and opportunities for engaging with market systems. Livestock Research for Rural Development. 26:3. Retrieved from http://www.Irrd.org/ Irrd26/3/ouma26056.htm.

Peirce, M. A. (1974). Distribution and ecology of Ornithodoros moubata porcinus Walton (Acarina) in animal burrows in East Africa. Bulletin of Entomological Research. 64:605-619. 10.1017/S0007485300035896

Penrith, M. L. (2012). History of 'swine fever' in southern Africa. Journal of the South African Veterinary Association. 84:1-6. https://doi. org/10.4102/jsava.v84i1.1106.

Penrith, M. L., Bastos, A. D., Etter, E. M. C., \& Beltrán-Alcrudo, D. (2019). Epidemiology of African swine fever in Africa today: Sylvatic cycle versus socio-economic imperatives. Transboundary and Emerging Diseases. 66:672-686. https://doi.org/10.1111/tbed.13117

Penrith, M. L., Lopes Pereira, C., Lopes da Silva, M. M. R., Quembo, C., Nhamusso, A., \& Banze, J. (2007). Overview of African swine fever in Mozambique: Risk factors and potential for control. Onderstepoort Journal of Veterinary Research. 74:149-160.

Penrith, M. L., Thomson, G. R., Bastos, A., Phiri, O. C., Lubisi, B. A., Du plessis, E. C., ... Esterhuysen, J. J. (2004). An investigation into natural resistance to African swine fever in domestic pigs from an endemic area in southern Africa. Revue Scientifique Et Technique, Office International Des Épizooties. 23:665-677. https://doi.org/10.20506/ rst.23.3.1533

Penrith, M. L., \& Vosloo, W. (2009). Review of African swine fever: Transmission, spread and control. Journal of the South African Veterinary Association. 80:58-62. https://doi.org/10.4102/jsava. v80i2.172.

Penrith, M. L., Vosloo, W., Jori, F., \& Bastos, A. D. S. (2013). African swine fever virus eradication in Africa. Virus Research. 173:228-246. https://doi.org/10.1016/j.virusres.2012.10.011

Petrus, N. P., Mpofu, I., Schneider, M. B., \& Nepembe, M. (2011). The constraints and potential of pig production among communal farmers in Etayi Constituency of Namibia. Livestock Research for Rural Development. 23:159. Retrieved from http://www.Irrd.org/Irrd23/7/ petr23159.htm.

Phologane, S. B., Bastos, A. D. S., \& Penrith, M.-L. (2005). Intra- and intergenotypic size variation in the central variable region of the $9 R L$ open reading frame of diverse African swine fever viruses. Virus Genes. 31:357-360. https://doi.org/10.1007/s11262-005-3254-z 
Plowright, W., \& Parker, J. (1967). The stability of African swine fever virus with particular reference to heat and $\mathrm{pH}$ inactivation. Archiv Für Gesamte Virusforschung. 21:383-402. https://doi.org/10.1007/ BF01241738

Plowright, W., Parker, J. A., \& Peirce, M. A. (1969a). African swine fever virus in ticks (Ornithodoros moubata Murray) collected from animal burrows in Tanzania. Nature. 221:1071-1073. https://doi. org/10.1038/2211071a0.

Plowright, W., Parker, J., \& Peirce, M. A. (1969b). The epizootiology of African swine fever in Africa. Veterinary Record. 85:668-674.

Plowright, W., Perry, C. T., \& Greig, A. (1974). Sexual transmission of African swine fever virus in the tick, Ornithodoros moubata porcinus Walton. Research in Veterinary Science. 17:106-113.

Plowright, W., Perry, C. T., \& Peirce, M. A. (1970). Transovarial infection with African swine fever virus in the argasid tick, Ornithodoros moubata porcinus Walton. Research in Veterinary Science. 11:82-584. https://doi.org/10.1016/S0034-5288(18)34259-0

Plowright, W., Perry, C. T., Peirce, M. A., \& Parker, J. (1970). Experimental infection of the argasid tick, Ornithodoros moubata porcinus, with African swine fever virus. Archiv Für Die Gesamte Virusforschung. 31:33-50. https://doi.org/10.1007/BF01241664

Plowright, W., Thomson, G. R., \& Neser, J. A. (1994). African swine fever. In Coetzer, J. A. W., Thomson, G. R., \& Tustin, R. C. (Eds.), Infectious diseases of Livestock, with special reference to Southern Africa, 1 (pp. 568-599). Cape Town, South Africa:Oxford University Press South Africa.

Quembo, C., Jori, F., Heath, L., Pérez-Sánchez, R., \& Vosloo, W. (2016). Investigation into the epidemiology of African swine fever virus at the wildlife-domestic interface of the Gorongosa National Park, Central Mozambique. Transboundary and Emerging Diseases. 63:443451. https://doi.org/10.1111/tbed.12289

Quembo, C. J., Jori, F., Vosloo, W., \& Heath, L. (2018). Genetic characterisation of African swine fever isolates from soft ticks at the wildlife/ domestic interface in Mozambique and identification of a novel genotype. Transboundary and Emerging Diseases. 65:420-431. https:// doi.org/10.1111/tbed.12700

Randrianantoandro, T. N., Kono, H., \& Kubota, S. (2015). Knowledge and behaviour from an animal disease outbreak - evidence from an item count technique in a case of African swine fever in Madagascar. Preventive Veterinary Medicine. 118:483-487. https:// doi.org/10.1016/j.prevetmed.2014.12.016

Ravaomanana, J., Jori, F., Vial, L., Pérez-Sánchez, R., Blanco, E., Michaud, V., \& Roger, F. (2011). Assessment of interactions between African swine fever virus, bushpigs (Potamochoerus larvatus), Ornithodoros ticks and domestic pigs in north-western Madagascar. Transboundary and Emerging Diseases. 58:247-254. https://doi. org/10.1111/j.1865-1682.2011.01207.x

Ravaomanana, J., Michaud, V., Jori, F., Andriatsimahavandy, A., Roger, F., Albina, E., \& Vial, L. (2010). First detection of African swine fever virus in Ornithodoros porcinus ticks in Madagascar and new insights into tick distribution and taxonomy. Parasites and. Vectors. 3:115. https://doi.org/10.1186/1756-3305-3-115

Rennie, L., Wilkinson, P. J., \& Mellor, P. S. (2001). Transovarial transmission of African swine fever virus in the argasid tick Ornithodoros moubata. Medical and Veterinary Entomology. 15:140-146.

Rock, D. L. (2017). Challenges for African swine fever vaccine development - "...perhaps the end of the beginning". Veterinary Microbiology. 206:52-58. https://doi.org/10.1016/j.vetmic.2016.10.0003

Roeder, P. (2011). Making a global impact: Challenges for the future. Veterinary Record. 169:671-674. https://doi.org/10.1136/vr.d8253

Roger, F., Ratovonjato, J., Vola, P., \& Uilenberg, G. (2001). Ornithodoros porcinus ticks, bushpigs, and African swine fever in Madagascar. Experimental and Applied Acarology. 25:263-269.

Rousset, D., Randriamparany, T., Maharavo Rahantamalala, C. Y., Randriamahefa, N., Zeller, H., Rakoto-Andrianarivelo, M., \& Roger, F. (2001).
Introduction de la peste porcine africaine à Madagascar, histoire et leçons d'une émergence. Archives De L'institut Pasteur De Madagascar. 67:31-33.

Rowlands, R. J., Michaud, V., Heath, L., Hutchings, G., Oura, C., Vosloo, W., ... Dixon, L. K. (2008). African swine fever virus isolate, Georgia 2007. Emerging Infectious Diseases. 14:1870-1874. https://doi. org/10.3201/eid1412.080591

Saliki, J. T., Thiry, E., \& Pastoret, P. P. (1985). La peste porcine africaine. Paris, France: Institut D'élevage et de Médecine Vétérinaire Des Pays Tropicaux.

Samui, K. L., Nambota, A. M., Mweene, A. S., \& Onuma, M. (1996). African swine fever in Zambia: Potential financial and production consequences for the commercial sector. Japanese Journal of Veterinary Research. 44:119-124. https://doi.org/10.14943/ jjvr.44.2.119

Samui, K. L., Mwanaumo, B., \& Chizyuka, H. G. B. (1991). African swine fever in Zambia - report on the first outbreak outside the endemic zone. Proceedings of the 6th International Symposium on Veterinary Epidemiology and Economics, 1991. Retrieved from www.sciquest. org.nz.

Sánchez Botija, C. (1963). Reservoirs of African swine fever virus/ a study of the African swine fevere virus in arthropods by means of haemadsorption. Bulletin De L'office International Des Épizooties. 60:895-899.

Sánchez Botija, C. (1982). Peste porcina Africana. Nuevos desarrollos. Revue Scientifique Et Technique De L'office International Des Épizooties. 1:991-1029. https://doi.org/10.20506/rst.1.4.91

Sánchez-Vizcaíno, J. M., Mur, L., \& Martínez-López, B. (2013). African swine fever (ASF): Five years around Europe. Veterinary Microbiology. 165:45-50. https://doi.org/10.1016/j.vetmic.2012.11.030

Simpson, V. R., \& Drager, N. (1979). African swine fever antibody detection in warthogs. Veterinary Record. 105:61. https://doi.org/10.1136/ vr.105.3.61

Simulundu, E., Chambaro, H. M., Sinkala, Y., Kajihara, M., Ogawa, H., Mori, A., ... Mweene, A. S. (2018). Co-circulation of multiple genotypes of African swine fever viruses among domestic pigs in Zambia (2013-2015). Transboundary and Emerging Diseases. 65:114-122. https://doi.org/10.1111/tbed.12635.

Simulundu, E., Lubaba, C., van Heerden, J., Kajihara, M., Mataa, L., Chambaro, H., ... Mweene, A. (2017). The epidemiology of African swine fever in "non-endemic" regions of Zambia (1989-2015): Implications for disease prevention and control. Viruses. 9:9. https:// doi.org/10.3390/v9090236

Simulundu, E., Sinkala, Y., Chambaro, H. M., Chinyemba, A., Banda, F., Mooya, L. E., ... Mweene, A. S. (2018). Genetic characterisation of African swine fever virus from 2017 outbreaks in Zambia: Identification of p72 genotype II variants in domestic pigs. Onderstepoort Journal of Veterinary Research. 85:a1562. https://doi. org/10.4102/ojvr.v85i1.1562

Souto, R., Mutowembwa, P., van Heerden, J., Fosgate, G. T., Heath, L., \& Vosloo, W. (2016). Vaccine potential of two previously uncharacterized African swine fever isolates from southern Africa and heterologous protection from an avirulent European isolate. Transboundary and Emerging Diseases. 63:224-231. https://doi.org/10.1111/ tbed.12250

Ståhl, K., Ogweng, P., Okoth, E., Aliro, T., Muhangi, D., \& LeBlanc, N., ... Masembe, C., (2014). Understanding the dynamics and spread of African swine fever virus at the wildlife-livestock interface: Insights into the potential role of the bushpig, Potamochoerus larvatus. Suiform Soundings. 13:24-28.

Steyn, D. G. (1928). Preliminary report on a South African virus disease amongst pigs. $13^{\text {th }}$ and $14^{\text {th }}$ Reports of the Director of Veterinary Education and Research, Union of South Africa, 415-428.

Steyn, D. G. (1932). East African virus disease in pigs. $18^{\text {th }}$ Report of the Director of Veterinary Services and Animal Industry, Union of South Africa, 1, 99-109. 
Swai, E. S., \& Lyimo, C. J. (2014). Impact of African swine fever epidemics in smallholder pig production units in Rombo district of Kilimanjaro, Tanzania. Livestock Research for Rural Development. 26:2. http://www. Irrd.org/Irrd/26/2/SWAI26032.html.

Swai, E. S., Hayghaimo, A. A., Hassan, A. A., \& Mhina, B. S. (2015). The slaughter of increased numbers of pregnant cows in Tanga abattoir, Tanzania: A cause for concern? Onderstepoort Journal of Veterinary Research, 82:E1-E5. https://doi.org/10.4102/ojvr.v82i1.947.

Tekle, T., Tesfay, A., \& Kifleyohannes, T. (2013). Smallholder pig production and its constraints in Mekelle and southern zone of Tigray Region, north Ethiopia. Livestock Research for Rural Development. 25:10. Retrieved from http://www.Irrdlorg//rrd25/10/tekl.25184.htm.

Thierry, B., \& Capo-Chichi, M. (2008). L'élevage porcin dans la region d'Analanjirofo à Madagascar. Etude_porciculture_FIDA_Madagascar. pdf[832.70kB]. Retrieved from http://pigtrop.cirad.fr.

Thomas, L. F., Bishop, R. P., Onzere, C., Mcintosh, M. T., Lemire, K. A., de Glanville, W. A., ... Fèvre, E. M. (2016). Evidence for the presence of African swine fever virus in an endemic region of Western Kenya in the absence of any reported outbreak. BMC Veterinary Research. 12:192. https://doi.org/10.1186/s12917-016-0830-5

Thomson, G. R. (1985). The epidemiology of African swine fever: The role of free-living hosts in Africa. Onderstepoort Journal of Veterinary Research. 52:201-209.

Thomson, G. R., Gainaru, M., Lewis, A., Biggs, H., Nevill, E., \& van der Pypekamp, H., ... Condy, J. (1983). The relationship between African swine fever virus, the warthog and Ornithodoros species in southern Africa. In: P. J. Wilkinson (Ed.) African Swine Fever. EUR 8466 EN. Luxembourg: Commission of the European Communities.

Thomson, G. R., Gainaru, M. D., \& Van Dellen, A. F. (1979). African swine fever: Pathogenicity and immunogenicity of two non-haemadsorbing viruses. Onderstepoort Journal of Veterinary Research. 46:149-154.

Thomson, G. R., Gainaru, M. D., \& Van Dellen, A. F. (1980). Experimental infection of warthogs with African swine fever virus. Onderstepoort Journal of Veterinary Research. 47:19-22.

Turnbull, D. O. (1932). Nyasaland. Annual Report of the Veterinary Department, 1931. Swine fever.

Turnbull, D. O. (1933). Nyasaland. Annual Report of the Veterinary Department, 1932. Swine fever.

Turnbull, D. O. (1934). Nyasaland. Annual Report of the Veterinary Department, 1933. Swine fever.

Uilenberg, G., Estrada-Peña, A., \& Thal, J. (2013). Ticks of the Central African Republic. Experimental and Applied Acarology. 50:1-40. https://doi.org/10.1007/s10493-012-9605-2

Uttenthal, Á., Braae, U. C., Ngowi, H., Rasmussen, T. B., Nielsen, J., \& Johansen, M. V. (2013). ASFV in Tanzania: Asymptomatic pigs harbor virus of molecular similarity to Georgia 2007. Veterinary Microbiology. 165:173-176. https://doi.org/10.1016/j. vetmic.2013.01.003

Van Heerden, J., Malan, K., Gadaga, B. M., \& Spargo, R. E. (2017). Reemergence of African swine fever in Zimbabwe, 2015. Emerging Infectious Diseases. 23:860-861. https://doi.org/10.3201/ eid2305.161195

Veary, C. M., \& Manoto, S. N. (2008). Neurocysticercosis: A possible cause of epileptiform seizures in people residing in villages served by the Bethanie Clinic in the North West Province of South Africa. Journal of the South African Veterinary Association. 79:84-88. https:// doi.org/10.4102/jsava.v79i2.249

Vergne, T., Chen-Fu, C., Li, S., Cappelle, J., Edwards, J., Martin, V., ... Roger, F. L. (2017). Pig empire under infectious threat: Risk of African swine fever introduction into the People's Republic of China. Veterinary Record. 181:117. https://doi.org/10.1136/ vr.103950

Wambura, P. N., Masambu, J., \& Msami, H. (2006). Molecular diagnosis and epidemiology of African swine fever outbreaks in Tanzania. Veterinary Research Communications. 30:667-672. https://doi. org/10.1007/s11259-006-3280-x

Wilkinson, P. J. (1984). The persistence of African swine fever in Africa and the Mediterranean. Preventive Veterinary Medicine. 2:71-82. https://doi.org/10.1016/0167-5877(84)90050-3

Wilkinson, P. J., Pegram, R. G., Berry, B. D., Lemche, J., \& Schels, H. F. (1988). The distribution of African swine fever virus isolated from Ornithodoros moubata in Zambia. Epidemiology and Infection. 101:547-564. https://doi.org/10.1017/S0950268800029423

Wilson, R. T., \& Swai, E. S. (2014). Pig production in Tanzania: A critical review. Tropicultura. 32:46-53.

Yabe, J., Hamambulu, P., Simulundu, E., Ogawa, H., Kajihara, M., \& MoraKajihara, A., ... Mweene, A. S. (2015). Pathological and molecular diagnosis of the 2013 outbreak of African swine fever in Lusaka, Zambia. Tropical Animal Health and Production. 47:459-463. https:// doi.org/10.1007/s11250-014-0732-0

How to cite this article: Mulumba-Mfumu LK, Saegerman C, Dixon LK, et al. African swine fever: Update on Eastern, Central and Southern Africa. Transbound Emerg Dis. 2019;00:1-19. https://doi.org/10.1111/tbed.13187 